\title{
Biomass Feedstock Pre-Processing - Part 1: Pre-Treatment
}

\author{
Lope Tabil ${ }^{1}$, Phani Adapa ${ }^{1}$ and Mahdi Kashaninejad ${ }^{2}$ \\ ${ }^{1}$ Department of Chemical and Biological Engineering, University of Saskatchewan \\ 2Department of Food Science E Technology, Gorgan University of Agricultural \\ Sciences and Natural Resources Gorgan \\ ${ }^{1}$ Canada \\ ${ }^{2}$ Iran
}

\section{Introduction}

\subsection{Sources of biomass}

The two main sources of biomass for energy generation are purpose-grown energy crops and waste materials (Larkin et al., 2004). Energy crops, such as Miscanthus and short rotation woody crops (coppice), are cultivated mainly for energy purposes and are associated with the food vs. fuels debate, which is concerned with whether land should be used for fuel rather than food production. The use of residues from agriculture, such as barley, canola, oat and wheat straw, for energy generation circumvents the food vs. fuel dilemma and adds value to existing crops (Chico-Santamarta et al., 2009). In fact, these residues represent an abundant, inexpensive and readily available source of renewable lignocellulosic biomass (Liu et al., 2005).

\subsection{Current issues related to biomass utilization}

The main problem with agricultural straw is its relatively low density in its original or baled forms. The bulk density of loose and standard baled straw is approximately $40 \mathrm{~kg} / \mathrm{m}^{3}$ and $100 \mathrm{~kg} / \mathrm{m}^{3}$, respectively, compared with the bulk density of unprocessed wood residue, which is approximately $250 \mathrm{~kg} / \mathrm{m}^{3}$ (Demirbaş, 2001; Tripathi et al., 1998). The relative low density of straw makes it more expensive to transport compared to wood and coal because a lower mass of straw can be transported per unit volume. Additionally, a larger storage area/volume is required for baled straw compared to wood chip. Densification into pellets increases the bulk density of biomass (McMullen et al., 2005; Obernberger and Thek ,2004) and as a result, the net calorific content per unit volume is increased (Bhattacharya et al., 1989) and the storage, transport and handling of the material is easier and cheaper (Balatinecz, 1983; Bhattacharya et al., 1989; Kaliyan and Morey, 2006).

The quality of fuel pellet is usually assessed based on its density and durability. High bulk density increases storage and transport capacity of pellets (Adapa et al., 2007; Mani et al., 2003). Since feeding of boilers and gasifiers generally is volume-dependent, variations in bulk density should be avoided (Larsson et al., 2008). A bulk density of $650 \mathrm{~kg} / \mathrm{m}^{3}$ is stated as design value for wood pellet producers (Obernberger and Thek 2004). Low durability of pellets results in problems like disturbance within pellet feeding systems, dust emissions, 
and increased risk of fire and explosions during pellet handling and storage (Temmerman et al. 2006).

Densification of straw and determining the optimal parameters involved is an art in itself. The entire process involves securing of baled straw from agricultural fields, size reduction (chopping and grinding), application of pre-treatment (chemical, physico-chemical, and biological), determining the physical and frictional properties of straw grinds, lignocellulosic characterization of straw, lab-scale and pilot-scale densification of grinds into pellets to determine the effect of various independent parameters on quality (density and durability), and energy analysis/ balance (Fig. 1). This chapter will only address the effect and need of lignocellulose characterization, pre-treatment and size reduction, and physical properties on densification of agricultural straw.

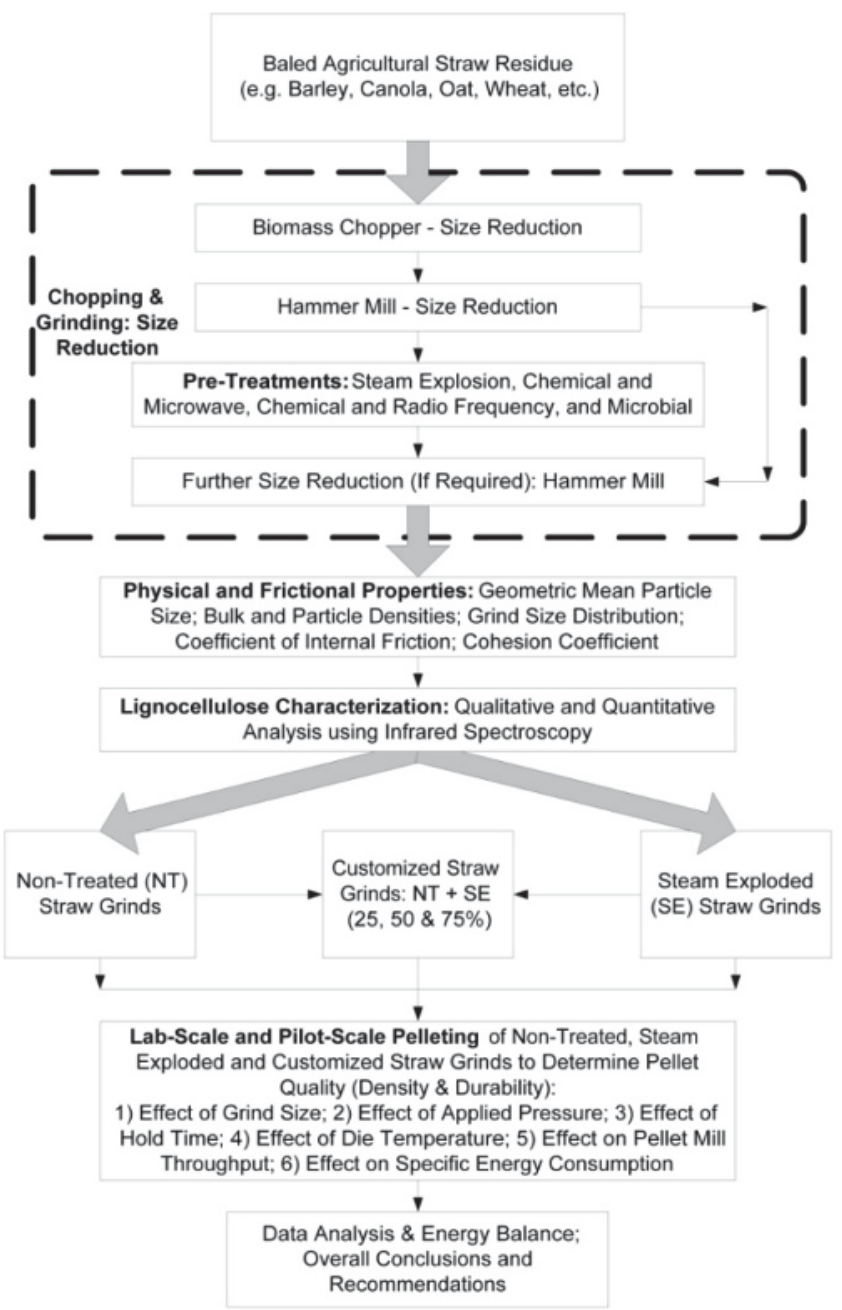

Fig. 1. Processing steps involved in converting straw from field to pelletized product. 


\section{Lignocellulosic biomass characterization}

\subsection{Structure of lignocellulosic material}

Lignocellulosic material refers to plant biomass that is composed of cellulose, hemicellulose, and lignin (Fig. 2) (Lin and Tanaka, 2006). The major combustible component of non-food energy crops is cellulose, followed by lignin.

Cellulose: Cellulose is an organic polysaccharide consisting of a linear chain of several hundreds to over nine thousand $\beta(1 \rightarrow 4)$ linked D-glucose $\left(\mathrm{C}_{6} \mathrm{H}_{10} \mathrm{O}_{5}\right)$ n units (Crawford, 1981; Updegraff, 1969). Cellulose, a fibrous, tough, water-insoluble substance, is found in the cell walls of plants, particularly in the stalks, stems, trunks and all the woody portions of the plant body (Nelson and Cox, 2005). Cellulose comprises $40-60 \%$ of the dry weight of plant material (the cellulose content of cotton is $90 \%$ and that of wood is 50\%) (Encyclopædia Britannica, 2008; USDE, 2006).

Zandersons et al. (2004) and Shaw (2008) reported that binding of wood material during hot pressing / densification is mainly dependent on the transition of cellulose into the amorphous state. According to Hon (1989), due to the semi-crystalline structure, hydrogen bonded cellulose cannot be dissolved easily in conventional solvents, and it cannot be melted before it burns; hence, cellulose itself is not a suitable adhesive. This can be overcome by breaking the hydrogen bonds, thus making the cellulose molecule more flexible (Hon 1989). Cellulose requires a temperature of $320^{\circ} \mathrm{C}$ and pressure of $25 \mathrm{MPa}$ to become amorphous in water (Deguchi et al., 2006).

Hemicellulose: Hemicellulose is made of several heteropolymers (matrix polysaccharides) present in almost all plant cell walls along with cellulose (Fig. 2). While cellulose is crystalline, strong, and resistant to hydrolysis; hemicellulose has a random, amorphous structure with less strength. Hemicellulose is a polysaccharide related to cellulose and comprises $20-40 \%$ of the biomass of most plants. In contrast to cellulose, hemicellulose is derived from several sugars in addition to glucose, including especially xylose but also mannose, galactose, rhamnose and arabinose (Shambe and Kennedy, 1985). Branching in hemicellulose produces an amorphous structure that is more easily hydrolyzed than cellulose (Shaw, 2008). Also, hemicellulose can be dissolved in strong alkali solutions. Hemicellulose provides structural integrity to the cell. Some researchers believe that natural bonding may occur due to the adhesive properties of degraded hemicellulose (Bhattacharya et al., 1989).

Lignin: Lignin is a complex chemical compound most commonly derived from wood and is an integral part of the cell walls of plants (Lebo et al., 2001; Zandersons et al., 2004). The compound has several unusual properties as a biopolymer, not the least its heterogeneity in lacking a defined primary structure. Lignin fills the spaces in the cell wall between cellulose and hemicellulose (Fig. 2). It is covalently linked to hemicellulose and thereby crosslinks different plant polysaccharides, conferring mechanical strength to the cell wall and consequently to the whole plant structure (Chabannes et al., 2001).

Lignin acts as a binder for the cellulose fibres (Fig. 2). van Dam et al. (2004) have reported that lignin can be used as an intrinsic resin in binderless board production due to the fact that when lignin melts (temperatures above $140^{\circ} \mathrm{C}$ ), it exhibits thermosetting properties. Lignin is the component that permits adhesion in the wood structure, and is a rigidifying and bulking agent (Anglès et al., 2001). Lehtikangas (2001) reported that water $(8-15 \%)$ in pellets will reduce the softening temperature of lignin to $100-135^{\circ} \mathrm{C}$ by plasticizing the molecular chains. The adhesive properties of thermally softened lignin are thought to contribute considerably to the strength characteristics of briquettes made of lignocellulosic materials (Granada et al., 2002; Shaw, 2008). 


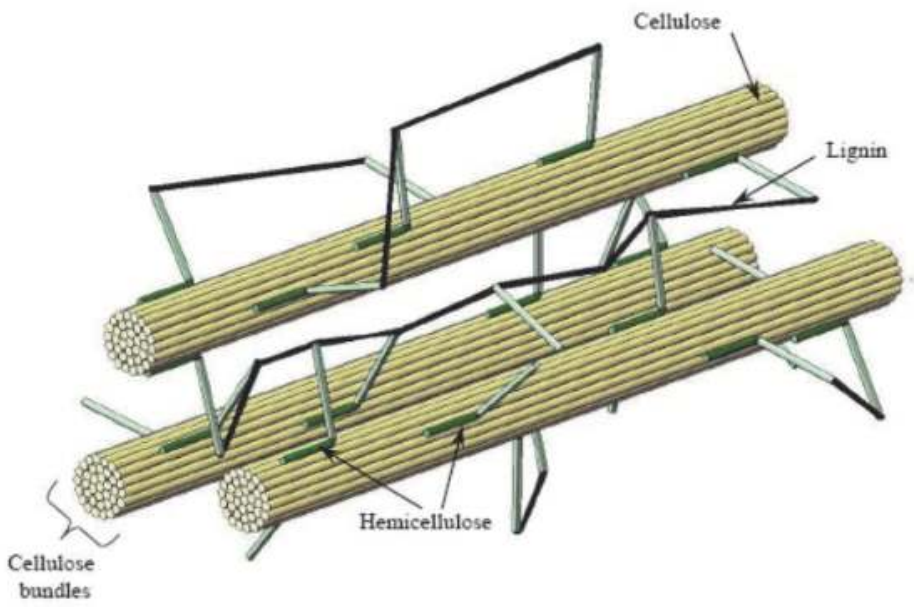

Fig. 2. Location and arrangement of cellulose microfibrils in plant cell walls (Murphy and McCarthy, 2005; Shaw, 2008).

\subsection{Rapid characterization of lignocellulosic materials}

The effect of various pre-processing and pre-treatment methods (Fig. 1) on the lignocellulosic matrix at the molecular level is not well understood. Applications of preprocessing methods such as size reduction or increasing porosity, and pre-treatment techniques such as steam explosion on agricultural biomass have demonstrated an improvement in pellet (compact) quality that can be attributed to the changes in the lignocellulosic components and distribution (Bagby, 1982; Focher et al., 1998). Therefore, it is critical to rapidly quantify the change in cellulose, hemicelluloses and lignin components of biomass due to application of pre-treatment methods.

Infrared spectroscopy has the potential to produce qualitative and quantitative analytical data for samples with minimum or no sample preparation, and at high speed and throughput (Adapa et al., 2011b and 2009; Budevska, 2002; Luypaert et al., 2003; Smola and Urleb, 2000; Tucker et al., 2000). Traditionally, chemical analyses of the individual components (e.g., lignin) of lignocellulosics have been performed by acid hydrolysis followed by gravimetric determination of lignin (Kelley et al., 2004). These methods can provide highly precise data. However, these methods are laborious, time-consuming, and, consequently, expensive to perform and sample throughput is limited.

\subsection{Fourier transform infrared spectroscopy}

Fourier Transform Infrared Spectroscopy (FTIR) can be used to rapidly characterize and quantify cellulose-hemicellulose-lignin composition prior to and after application of various methods of pre-processing and pre-treatment of biomass (Adapa et al., 2009). The quantitative analysis of FTIR absorption spectrometry is based on the Bouguer-BeerLambert law (Sherman Hsu, 1997). According to this law, the intensities of absorption bands are linearly proportional to the concentration of each component in a homogenous mixture or solution.

Regression equations to predict the lignocellulosic content of agricultural biomass can be developed using pure cellulose, hemicelluloses and lignin as reference samples, and 
subsequently mixing them in different proportions to determine the change in absorption intensity at characteristic peak height (Adapa et al., 2011b). An overview of the experimental procedure to characterize the lignocellulosic composition is provided in Figure 3.

Pure cellulose has five distinct characteristic/ prominent peaks at wavenumbers of 1431, 1373, 1338, 1319 and $1203 \mathrm{~cm}^{-1}$. Similarly, hemicellulose (xylan) has prominent peaks at wavenumbers of 1606, 1461, 1251, 1213, 1166 and $1050 \mathrm{~cm}^{-1}$. The lignin spectrum has characteristic peaks at wavenumber of 1599, 1511, 1467, 1429, 1157 and $1054 \mathrm{~cm}^{-1}$. The intensity of absorption at characteristic peak heights of cellulose, hemicellulose and lignin were used to develop regression equations to predict lignocellulosic composition of any agricultural biomass (Table 1) (Adapa et al., 2011b).

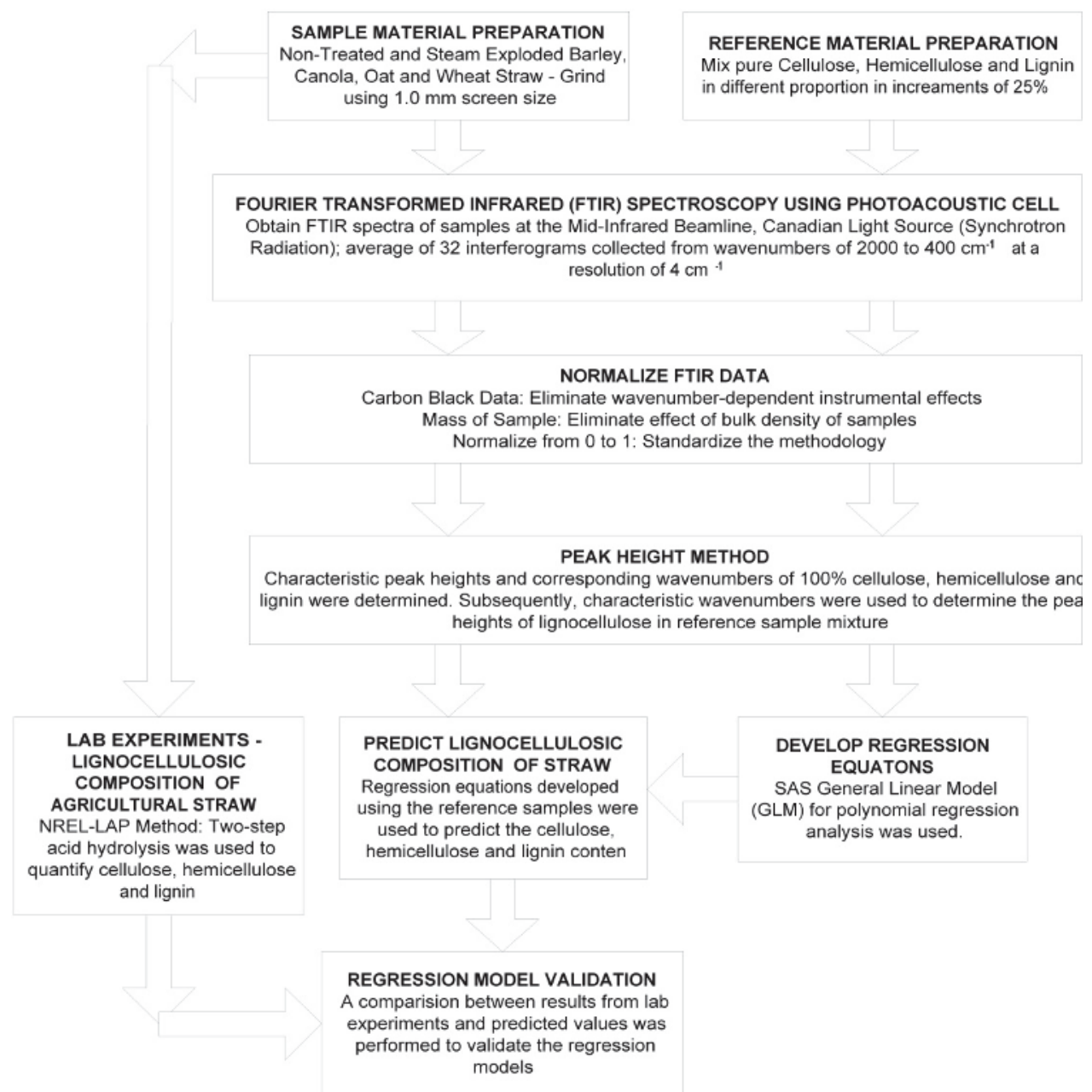

Fig. 3. Experimental procedure followed to characterize lignocellulosic composition of agricultural straw (Adapa et al., 2011b). 


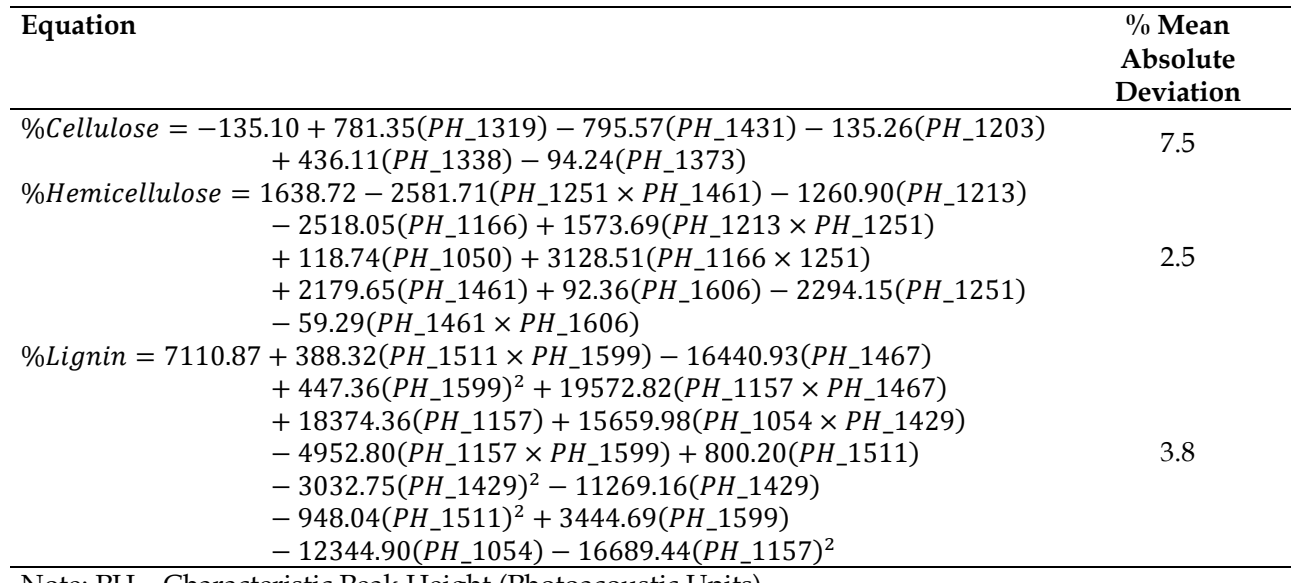

Note: PH - Characteristic Peak Height (Photoacoustic Units)

Table 1. Regression equations to predict the lignocellulosic composition of agricultural biomass (Adapa et al., 2011b).

\section{Pre-treatment of lignocellulosic biomass}

\subsection{Need for pre-treatment}

Upon densification, many agricultural biomass materials, especially those from straw and stover, result in a poorly formed pellets or compacts that are more often dusty, difficult to handle and costly to manufacture. This is caused by lack of complete understanding on the natural binding characteristics of the components that make up biomass (Sokhansanj et al., 2005). The natural binding characteristics of lignocellulosic biomass can be enhanced by modifying the structure of cellulose-hemicellulose-lignin matrix by application of preprocessing and pre-treatment methods (Sokhansanj et al. 2005). It is postulated that by disrupting the lignocellulosic matrix of biomass materials via application of various chemical, physico-chemical (steam explosion, microwave, and radio frequency heating), and biological pre-treatment, the compression and compaction characteristics can be improved (Shaw 2008; Kashaninejad and Tabil, 2011). When high molecular amorphous polysaccharides are reduced to low molecular components, the polymer becomes more cohesive in the presence of moisture (Chen et al., 2004). The cellulose-hemicellulose-lignin matrix can be broken down to smaller amorphous molecules through acid or alkaline hydrolysis as well as through steam explosion (Ladisch, 1989; Vlasenko, 1997). Alkaline or acid solutions are often used for pre-treatment of biomass and the effect of pre-treatment depends on the lignin content of biomass. When biomass is treated with dilute alkaline solution, the internal surface area of the material is increased by swelling. Swelling causes a decrease in the degree of polymerization, separation of structural linkages between lignin and carbohydrates and disruption of the lignin structure (Fan et al., 1987). Increased moisture content resulting from chemical and enzymatic treatments is a problem, as the treated biomass has to be dried prior to densification. Steam explosion results in the hemicelluloses being hydrolyzed and water soluble, the cellulose is slightly depolymerized, the lignin melts and is depolymerized, which aid in binding particles together during densification. Zandersons et al. (2004) stated that activation of lignin and changes in the cellulosic structure during the steam explosion process facilitate the formation of new 
chemical bonds. Lam et al. (2008) reported that the quality (durability) of compacts produced from steam exploded sawdust was $20 \%$ higher than non-treated sawdust.

\subsection{Physico-chemical pre-treatments \\ 3.2.1 Steam explosion}

Steam explosion is one of the most applied pre-treatment processes owing to its low use of chemicals and limited energy consumption (Harmsen et al., 2010). During steam explosion pre-treatment process, the lignocellulosic biomass is heated with high pressure saturated steam having temperatures typically in the range of $180-230^{\circ} \mathrm{C}$ for $2-10$ minutes. Subsequently, the substrate is quickly flashed to atmospheric pressure; as a result, the water inside the substrate vaporizes and expands rapidly, disintegrating the biomass (Grous et al., 1985; Kokta and Ahmed, 1998; Zimbardi et al., 1999). This causes great reduction in the particle size of the substrate (Fig. 4). The heart of the explosion pulping process is the reactor, which allows the use of high pressure during heating and cooking. The reactor can be of either the batch (Fig. 5) (Jin and Chen, 2006) or continuous type (Fig. 6) (Kokta and Ahmed, 1998; Adapa et al., 2010a).

Non-Treated

Steam Exploded

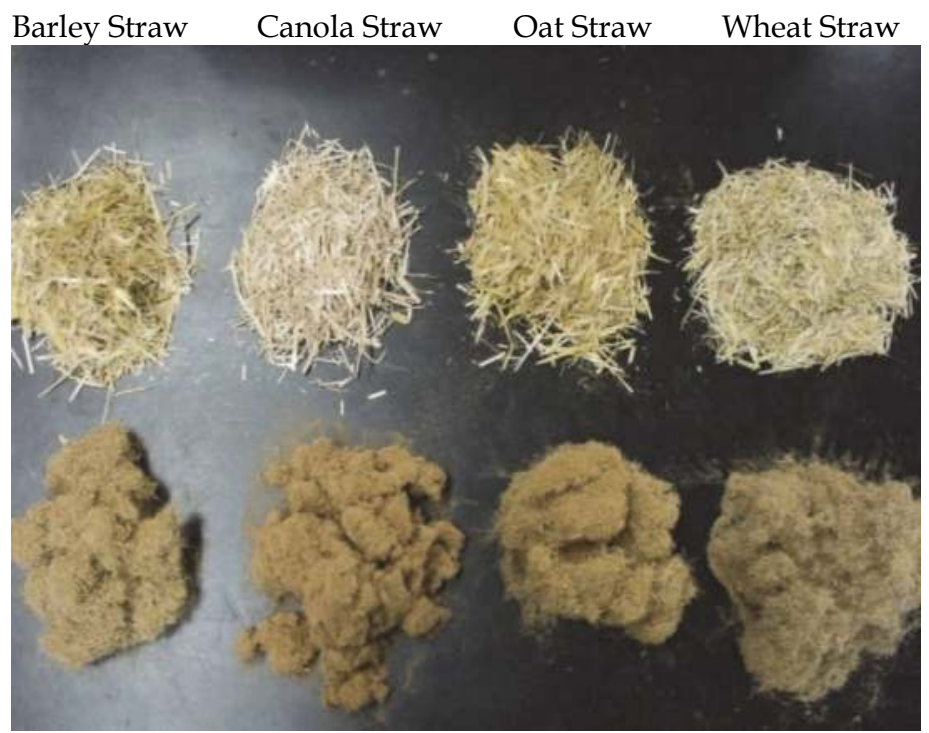

Fig. 4. Photographs showing the non-treated (30 mm hammer mill screen size) and steam exploded barley, canola, oat and wheat straw grinds.

The extent of chemical and structural modifications from steam-explosion pre-treatment depends on residence time, temperature, particle size and moisture content (Sun and Cheng, 2002). However, the severity (Ro) of steam explosion is quantified as a function of retention time and reaction temperature (Equation 1) (Overend and Chornet, 1987; Viola et al. 2008).

$$
\text { Ro }=t \times \exp \left(\frac{T-100}{14.75}\right)
$$


Where $T$ is the temperature in ${ }^{\circ} \mathrm{C}$ and $t$ is the time in minutes.

According to Zimbardi et al. (1999), the simplest way to carry out steam explosion is by batch procedure, hence widely reported in literature. However, the continuous reactors are of major interest for industrial applications. They have indicated that although the products obtained at the same treatment, severity in batch and continuous reactors are macroscopically different at first sight, there is still a lack of understanding to explain these differences. Consequently, they have developed experimental relationships between the two systems useful in making the data transfer straightforward (Equation 2).

$$
\log (R o)_{\text {Batch }}=1.50 \times\left(\log (R o)_{\text {Continuous }}-1\right)
$$

In addition, studies have been carried out to try to improve the results of steam explosion by addition of chemicals such as acid or alkali (Cara et al., 2008; Harmsen et al., 2010; Stenberg et al., 1998; Zimbardi et al., 2007). Limitations of steam explosion include the formation of degradation products that may inhibit downstream processes (Garcia-Aparicio et al., 2006).

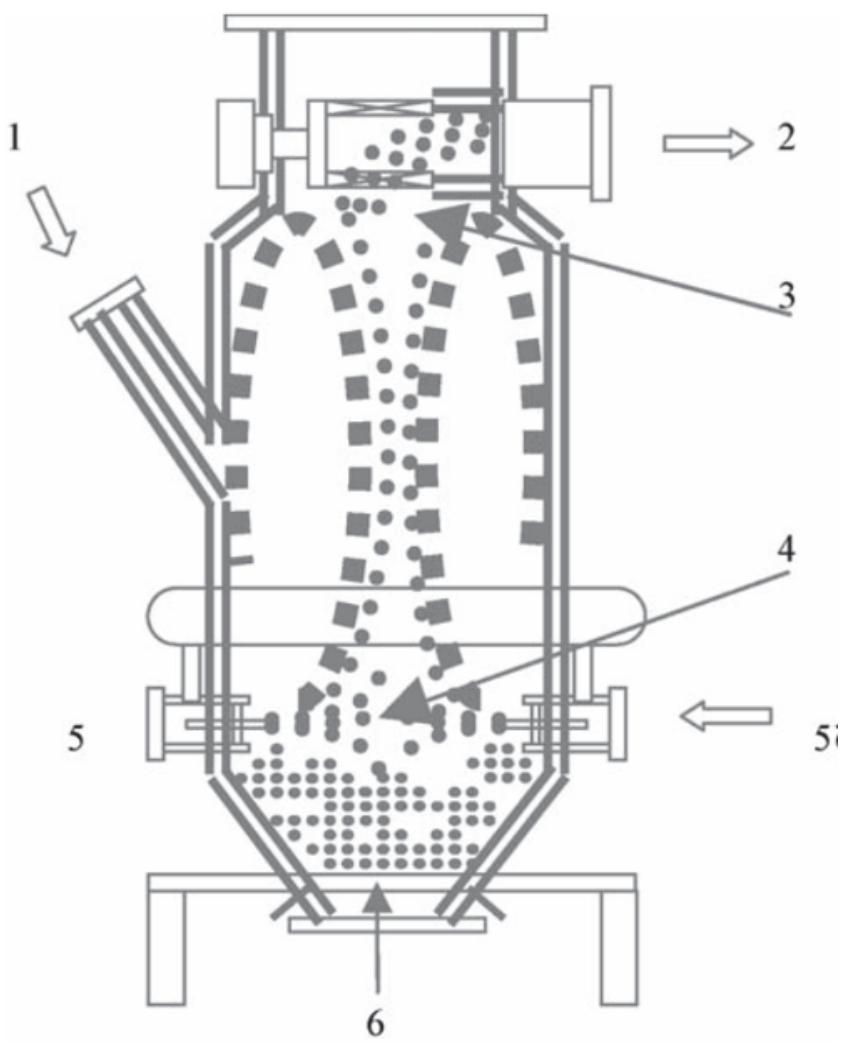

Fig. 5. Schematic diagram of the FJM-200 fluidized bed opposed jet mill. 1, Infeed; 2, collection; 3, classification section; 4 , grinding section; 5 , compressed air; 6 , discharge opening (Jin and Chen, 2006). 


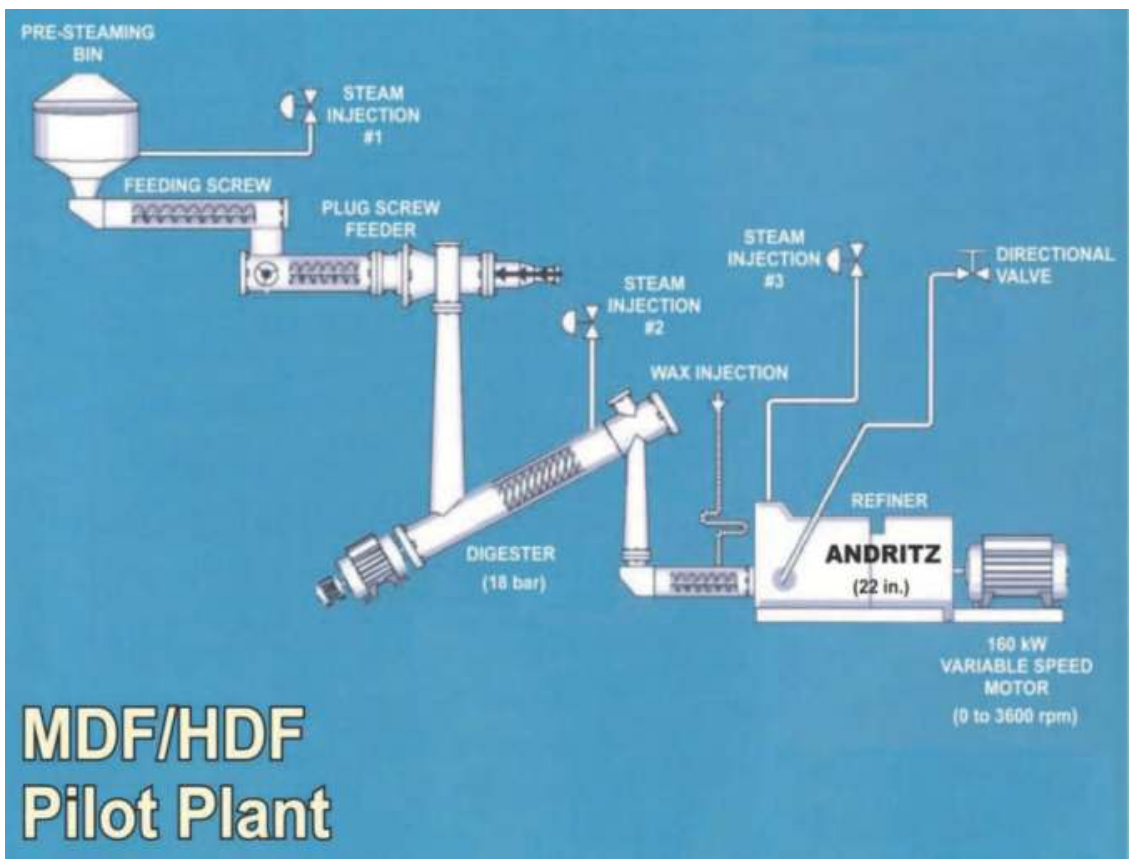

Fig. 6. The Andritz (ANDRITZ AG, Graz, Austria) continuous biomass steam explosion facility for manufacturing of Medium Density and High Density Fiberboards (MDF/HDF), Forintek pilot plant at the FPInnovations, Quebec City, Quebec (Adapa et al., 2010a).

\subsubsection{Microwave and radio frequency (RF) heating}

Dielectric heating is an alternative method to conventional heating. Unlike conduction/convection heating, which is based on superficial heat transfer, dielectric heating is based on volumetric and rapid heat transfer (de la Hoz et al., 2005). When lignocellulosic materials are placed in an electric field for dielectric heating pre-treatment, dipole molecules such as water or other dielectric materials, rotate vigorously to orient in the field. More polar components will absorb more energy, and thus, "hot spots" will be created in non-homogeneous materials. It is hypothesized that this unique heating feature results in an "explosion" effect in the particles and improves the disruption of the lignocellulosic structures. In addition, the non thermal effects of electromagnetic field accelerate the disintegration of the crystal structures (de la Hoz et al., 2005). Dielectric heating can be categorized as microwave or radio frequency depending on the wavelength used in the heating devices (Oberndorfer et al., 2000).

Microwave is electromagnetic waves between $300 \mathrm{MHz}$ (wavelength $1 \mathrm{~m}$ ) and $300 \mathrm{GHz}$ (wavelength $1 \mathrm{~mm}$ ). This range of spectrum lies between infrared and radio frequency radiation. Microwave irradiation has been extensively used in many processes because of its high heating efficiency and easy operation. Microwave energy can penetrate into materials and heat them quickly and uniformly. Microwave irradiation is considered to create thermal and non thermal effects. It has been applied as an efficient pre-treatment technique to enhance the hydrolysis of biomass materials. Some studies have demonstrated that 
microwave irradiation can change the structure of lignocellulosic materials and degrade or reduce lignin content, reduce cellulose crystallinity, and increase porosity and surface area of the materials (Azuma, 1984; Zhu et al., 2006b; Kashaninejad and Tabil, 2011).

This pre-treatment involves microwave irradiation of immersed biomass in an aqueous environment. Different types of lignocellulosic materials have been pre-treated using microwave irradiation including wheat straw (Ooshima et al., 1984; Zhu et al., 2006b; 2006c; Kashaninejad and Tabil, 2011), barley straw (Kashaninejad and Tabil, 2011), rice straw (Ooshima et al., 1984; Zhu et al., 2005; 2006a), rice hulls (Magara and Azuma, 1989), sugarcane bagasse (Ooshima et al., 1984; Magara and Azuma, 1989; Kitchaiya et al., 2003), switchgrass (Hu and Wen, 2008; Keshwani et al., 2007) and woody materials (Azuma et al., 1984). These materials were subjected to microwave pre-treatment of $2450 \mathrm{MHz}$ in the range of 250 to $1000 \mathrm{~W}$. The temperature of operation ranged from 70 to $230^{\circ} \mathrm{C}$, while heating time varied from 5 to 120 minutes. However, higher microwave power with short pre-treatment time and the lower microwave power with long pre-treatment time had almost the same effect on chemical composition of lignocellulosic materials (Zhu et al., 2005; 2006b; Kashaninejad and Tabil, 2011).

In order to increase the efficiency of microwave heating pre-treatment, some researchers have combined microwave treatment with alkaline treatment such as $\mathrm{NaOH}$ or $\mathrm{Ca}(\mathrm{OH})_{2}$. Some used alkaline solution during microwave heating treatment (Zhu et al., 2005; 2006a; 2006b; 2006c; Keshwani et al., 2007; Kashaninejad and Tabil, 2011) and some applied the alkaline solution before the lignocellulosic materials were subjected to microwave irradiation (Zhu et al., 2006a; Hu and Wen, 2008). Combination of microwave irradiation and alkali treatment improves the degradation of biomass by accelerating the reactions during the pre-treatment process compared with the conventional heating chemical pretreatment process. Remarkable changes (Table 2) have been reported in the chemical composition of biomass samples after microwave-alkali pre-treatment, particularly in hemicellulose, lignin, and cellulose contents (Kashaninejad and Tabil, 2011). It has been reported that alkali treatment dissolves lignin and hemicellulose, and microwave irradiation facilitates dissolving these components in alkali solutions (Jackson, 1977; Kumar et al., 2009; Lesoing et al., 1980; Zhu et al., 2005). Biomass samples pretreated by microwave-alkali technique have lower lignin, hemicellulose, and cellulose than samples pretreated by microwave-distilled water or untreated samples. Moreover, degradation and depolymerisation of lignin to smaller phenolic components is another influence of microwave-alkali pre-treatment that could be considered as binder in densification process. The pellets made from microwave-chemical pre-treated biomass grinds have significantly higher density and tensile strength (Table 3) than the untreated or samples pre-treated by microwave alone (Kashaninejad and Tabil, 2011).

Radio frequency $(\mathrm{RF})$ can penetrate more deeply into the materials compared with microwave heating because the radio frequency wavelength is up to 360 times greater than microwave (Marra et al., 2007). This unique characteristic is an advantage to treat large amount of material and it is easier to scale up the process. While radio frequency as a heating method has been widely applied in food-processing industries, there is not much report on application of radio frequency heating for lignocellulosic materials pre-treatment. $\mathrm{Hu}$ et al. (2008) used radio frequency heating in the $\mathrm{NaOH}$ pre-treatment of switchgrass to enhance its enzymatic digestibility. Because of the unique features of radio frequency heating (i.e., volumetric heat transfer, deep heat penetration of the samples, etc.), switchgrass could be treated on a large scale, at high solids content, and with a uniform 
temperature profile. At $20 \%$ solids content, radio frequency-assisted alkali pre-treatment (at $0.1 \mathrm{~g}$ of $\mathrm{NaOH} / \mathrm{g}$ of biomass loading and $90^{\circ} \mathrm{C}$ ) resulted in a higher xylose yield than the conventional heating pre-treatment. The optimal particle size and alkali loading in the radio frequency pre-treatment were determined to be $0.25-0.50 \mathrm{~mm}$ and $0.25 \mathrm{~g}$ of $\mathrm{NaOH} / \mathrm{g}$ of biomass, respectively.

\begin{tabular}{|c|c|c|c|c|c|c|c|c|c|c|c|c|}
\hline \multirow{2}{*}{ Treatment } & \multicolumn{6}{|c|}{ Wheat straw } & \multicolumn{6}{|c|}{ Barley straw } \\
\hline & Protein & Lignin & Ash & Starch & Cellulose & Hemicellulose & Protein & Lignin & Ash & Starch & Cellulose & Hemicellulose \\
\hline Untreated & $1.99 \mathrm{~b}$ & $8.33 a$ & $6.33 \mathrm{f}$ & $1.11 d$ & $44.99 \mathrm{~b}$ & $27.96 a$ & $1.61 \mathrm{~d}$ & $11.95 a$ & $6.03 \mathrm{~d}$ & $0.79 \mathrm{c}$ & $46.93 a$ & $27.40 \mathrm{a}$ \\
\hline $\begin{array}{l}\text { Microwave- } \\
\text { distilled } \\
\text { water }\end{array}$ & $2.24 \mathrm{a}$ & $8.01 \mathrm{c}$ & $8.87 \mathrm{e}$ & $1.48 \mathrm{~b}$ & $39.69 d$ & $22.62 b$ & $2.01 \mathrm{a}$ & $8.85 b$ & $6.28 \mathrm{~d}$ & $1.08 \mathrm{~b}$ & $45.25 b$ & $27.21 \mathrm{a}$ \\
\hline $\begin{array}{l}\text { Microwave- } \\
\mathrm{NaOH}(1 \%)\end{array}$ & $1.41 \mathrm{e}$ & $7.82 \mathrm{~d}$ & $17.32 b$ & $1.89 \mathrm{a}$ & $35.82 \mathrm{e}$ & $12.32 \mathrm{~d}$ & $1.80 \mathrm{~b}$ & $6.65 \mathrm{e}$ & $16.96 \mathrm{~b}$ & $0.60 \mathrm{e}$ & $40.81 \mathrm{c}$ & $8.74 \mathrm{c}$ \\
\hline $\begin{array}{l}\text { Microwave- } \\
\mathrm{NaOH}(2 \%)\end{array}$ & $1.36 \mathrm{f}$ & $7.09 \mathrm{f}$ & $34.77 \mathrm{a}$ & $0.27 f$ & $34.77 f$ & $4.06 \mathrm{f}$ & $1.62 d$ & $4.52 \mathrm{f}$ & $41.43 a$ & $0.54 \mathrm{f}$ & $35.22 \mathrm{~d}$ & $5.46 \mathrm{~d}$ \\
\hline $\begin{array}{c}\text { Microwave- } \\
\mathrm{Ca}(\mathrm{OH})_{2} \\
(1 \%)\end{array}$ & $1.85 \mathrm{c}$ & $8.11 b$ & $12.24 \mathrm{~d}$ & $0.69 \mathrm{e}$ & $45.66 a$ & $14.94 \mathrm{c}$ & $1.81 \mathrm{~b}$ & $7.27 \mathrm{~d}$ & $13.21 \mathrm{c}$ & $0.72 \mathrm{~d}$ & $41.01 \mathrm{c}$ & $15.00 \mathrm{~b}$ \\
\hline $\begin{array}{c}\text { Microwave- } \\
\mathrm{Ca}(\mathrm{OH})_{2} \\
(2 \%)\end{array}$ & $1.52 \mathrm{~d}$ & $7.55 \mathrm{e}$ & $15.89 \mathrm{c}$ & $1.31 \mathrm{c}$ & $42.56 c$ & $11.10 \mathrm{e}$ & $1.68 \mathrm{c}$ & $8.16 \mathrm{c}$ & $16.73 b$ & $1.19 \mathrm{a}$ & $41.24 \mathrm{c}$ & $8.97 \mathrm{c}$ \\
\hline
\end{tabular}

Means with the same letters designation $(a, b, c, d$, and e) in a column are not significantly different at $\mathrm{P}=0.05$.

Table 2. Chemical composition (\% dry basis) of untreated and microwave pretreated of wheat and barley straw at power $713 \mathrm{~W}$.

\begin{tabular}{cccccc}
\hline \multirow{2}{*}{ Treatment } & \multicolumn{2}{c}{ Wheat straw } & & \multicolumn{2}{c}{ Barley straw } \\
\cline { 2 - 3 } \cline { 5 - 6 } & Fracture load $(\mathrm{N})$ & $\begin{array}{c}\text { Tensile strength } \\
(\mathrm{MPa})\end{array}$ & & Fracture load (N) & $\begin{array}{c}\text { Tensile strength } \\
(\mathrm{MPa})\end{array}$ \\
\hline $\begin{array}{c}\text { Untreated } \\
\text { Microwave- distilled } \\
\text { water }\end{array}$ & $19.10 \pm 5.61$ & $0.81 \pm 0.24$ & & $16.25 \pm 5.30$ & $0.68 \pm 0.22$ \\
$\begin{array}{c}\text { Microwave- } \mathrm{NaOH} \\
(1 \%)\end{array}$ & $85.00 \pm 11.93$ & $1.48 \pm 0.46$ & & $14.25 \pm 5.31$ & $0.61 \pm 0.21$ \\
$\begin{array}{c}\text { Microwave- } \mathrm{NaOH} \\
(2 \%)\end{array}$ & $88.00 \pm 15.86$ & $3.69 \pm 0.66$ & & $90.75 \pm 22.42$ & $3.59 \pm 0.98$ \\
$\begin{array}{c}\text { Microwave- } \mathrm{Ca}(\mathrm{OH})_{2} \\
(1 \%)\end{array}$ & $67.05 \pm 19.82$ & $3.03 \pm 0.79$ & & $42.38 \pm 10.30$ & $1.83 \pm 0.49$ \\
$\begin{array}{c}\text { Microwave- } \mathrm{Ca}(\mathrm{OH})_{2} \\
(2 \%)\end{array}$ & $78.25 \pm 25.07$ & $3.31 \pm 1.03$ & & $67.25 \pm 19.94$ & $2.88 \pm 0.91$ \\
\hline
\end{tabular}

Table 3. Effect of microwave-chemical pre-treatments on fracture load and tensile strength of wheat and barley straw pellets at power $713 \mathrm{~W}$. 


\subsubsection{Chemical pre-treatment}

Different chemicals such as acids, alkalis, oxidizing agents and ozone have been used for chemical pre-treatment of lignocellulosic materials. Depending on the type of chemical used, pre-treatment could have different effects on structural components. Alkaline pre-treatment, ozonolysis, peroxide and wet oxidation pre-treatments were reportedly more effective in lignin removal, whereas dilute acid pre-treatment was more efficient in hemicellulose solubilization (Galbe and Zacchi, 2002; Sánchez and Cardona, 2008; Tomas-Pejo et al., 2008).

Acid Hydrolysis: Inorganic acids such as $\mathrm{H}_{2} \mathrm{SO}_{4}$ and $\mathrm{HCl}$ have been used for pre-treatment of lignocellulosic materials and have been used on a wide range of feedstocks ranging from hardwoods to grasses and agricultural residues. Acid hydrolysis can be classified as concentrated or dilute-acid hydrolysis based on the dose of acid used in the process. In the first case, the biomass is treated with high concentration of acids at ambient temperatures, which results in high conversion of lignocellulosic materials. Although concentrated acids are powerful agents for cellulose hydrolysis, they are toxic, corrosive, hazardous, and thus require reactors that are resistant to corrosion, making the pre-treatment process very expensive. In addition, the concentrated acid must be recovered after hydrolysis to make the process economically feasible (Galbe and Zacchi, 2002; Sun and Cheng, 2002).

Dilute-acid hydrolysis has been successfully developed for pre-treatment of lignocellulosic materials. Sulfuric acid at concentrations usually below $4 \%(\mathrm{wt})$ has been of the most interest in such studies as it is inexpensive and effective. Dilute $\mathrm{H}_{2} \mathrm{SO}_{4}$ pre-treatment can achieve high reaction rates and significantly improve cellulose hydrolysis (Esteghlalian et al., 1997). High temperature is favorable to attain acceptable rates of cellulose conversion. Despite low acid concentration and short reaction time, the use of high temperatures in dilute-acid hydrolysis accelerates the rate of hemicellulose sugar decomposition and increases equipment corrosion (Galbe and Zacchi, 2002; Taherzadeh and Karimi, 2007).

Alkali hydrolysis: Dilute alkali such as sodium, potassium, calcium, and ammonium hydroxides have been used for pre-treatment of lignocellulosic materials in alkali hydrolysis. The effectiveness of these agents depends on the lignin content of the materials. Temperature and pressure are lower in alkali pre-treatment compared with other pretreatment methods (Mosier et al., 2005). Alkali pre-treatment can be conducted at ambient conditions, but process time is longer (hours or days instead of minutes or seconds). Compared with acid process, alkaline process causes less sugar degradation, and many of the caustic salts can be recovered and/or regenerated.

Sodium hydroxide has been studied more than other agents (Soto et al., 1994; Fox et al., 1989; MacDonald et al., 1983). Treatment of lignocellulosic materials using dilute $\mathrm{NaOH}$ results in swelling, leading to an increase in internal surface area, a decrease in the degree of polymerization, a decrease in crystallinity, separation of structural linkages between lignin and carbohydrates, and disruption of the lignin structure. However, calcium hydroxide (lime) is the least expensive hydroxide and has been shown to be an effective pre-treatment agent. The process of lime pre-treatment involves slurrying the lime with water, spraying it onto the biomass material, and storing the material in a pile for a period of hours to weeks. The particle size of the biomass is typically $10 \mathrm{~mm}$ or less. Elevated temperatures reduce contact time.

Oxidizing agents: In this pre-treatment, an oxidizing compound such as hydrogen peroxide $\left(\mathrm{H}_{2} \mathrm{O}_{2}\right)$ or peracetic acid $\left(\mathrm{CH}_{3} \mathrm{CO}_{3} \mathrm{H}\right)$ is used to treat lignocellulosic materials and sometimes is applied in combination of an alkaline solution (e.g. $\mathrm{NaOH}$ ) to improve effectiveness. This 
pre-treatment is usually carried out under mild temperature. This pre-treatment is more effective to increase crop residue digestibility compared with $\mathrm{NaOH}$ pre-treatment alone. Gould (1984) delignified agricultural residues using $1 \% \mathrm{H}_{2} \mathrm{O}_{2}$ at $25^{\circ} \mathrm{C}$ for $18-24 \mathrm{~h}$. Under this condition, more than half of the lignin and most of hemicellulose were solubilized. The pretreatment of cane bagasse with $\mathrm{H}_{2} \mathrm{O}_{2}$ greatly enhanced its susceptibility to further hydrolysis. About $50 \%$ of the lignin and most of the hemicellulose were solubilized by $2 \%$ $\mathrm{H}_{2} \mathrm{O}_{2}$ at $30^{\circ} \mathrm{C}$ within $8 \mathrm{~h}$, and a $95 \%$ efficiency of glucose production from cellulose was achieved in the subsequent saccharification by cellulase at $45^{\circ} \mathrm{C}$ for $24 \mathrm{~h}$ (Azzam, 1989).

Ozonolysis: In this process, ozone is used to change the structure of lignocellulosic materials and has been used for different materials such as wheat straw (Ben-Ghedalia and Miron, 1981), bagasse, green hay, peanut, pine ( Neely, 1984), cotton straw (Ben-Ghedalia and Shefet, 1983) and poplar sawdust (Vidal and Molinier, 1988). Ozonolysis is carried out at room temperature and normal pressure. It can effectively remove the lignin without producing any toxic residues. In this process, hemicellulose is slightly affected, but no change in cellulose has been reported. The main restriction of this process is the large amount of ozone utilization that makes the process expensive (Sun and Cheng, 2002). Binder et al. (1980) reported 60\% removal of the lignin from wheat straw using ozone pretreatment. Enzymatic hydrolysis yield increased from $0 \%$ to $57 \%$ as the percentage of lignin decreased from $29 \%$ to $8 \%$ after ozonolysis pre-treatment of poplar sawdust (Vidal and Molinier, 1988). Garcia-Cubero et al. (2009) studied the ozonolysis pre-treatment of wheat straw in a fixed bed reactor at room conditions and concluded that enzymatic hydrolysis yield of up to $88.6 \%$ compared to $29 \%$ in non-ozonated sample.

\subsection{Biological pre-treatment}

Most pre-treatments require expensive instruments or equipment that require high energy requirements, depending on the process. In particular, physical and thermo-chemical processes require ample amount of energy to change the lignocellulosic structure of biomass. Biological pre-treatment using various types of rot fungi is a process that does not require high energy for lignin removal from a lignocellulosic biomass, despite extensive lignin degradation. Biological pre-treatments are safe, environmentally friendly and less energy intensive compared to other pre-treatment methods. However, the rate of hydrolysis reaction is very slow and needs a great improvement to be commercially applicable.

Biological pre-treatment comprises of using microorganisms such as brown-, white-, and soft-rot fungi for selective degradation of lignin and hemicellulose among which white-rot fungi seems to be the most effective microorganism (Fan et al., 1987). Brown rots mainly attack cellulose, while white and soft rots attack both cellulose and lignin. Lignin degradation occurs through the action of lignin-degrading enzymes such as peroxidases and laccase (Okano et al., 2005). These enzymes are regulated by carbon and nitrogen sources. The suitable fungi for biological pre-treatment should have higher affinity for lignin and degrade it faster than carbohydrate components.

Hatakka et al. (1983) studied the pre-treatment of wheat straw by 19 white-rot fungi and found that $35 \%$ of the straw was converted to reducing sugars by Pleurotus ostreatus in 5 weeks. Similar conversion was obtained in the pre-treatment by Phanerochaete sordid (Ballesteros et al., 2006) and Pycnoporus cinnabarinus (Okano et al., 2005) in 4 weeks. Akin et al. (1995) also reported the delignification of bermudagrass by white-rot fungi. The biodegradation of bermudagrass stems was improved by 29-32\%, after 6 weeks, using Ceriporiopsis subvermispora and by $63-77 \%$ using Cyathus stercoreus. 


\section{Particle size reduction and physical properties}

The application of pre-processing operations such as particle size reduction/ grinding is critical in order to increase the surface area of lignocellulosic biomass prior to densification (Mani et al. 2004). Particle size reduction increases the total surface area, pore size of the material and the number of contact points for inter-particle bonding in the compaction process (Drzymala, 1993). Size reduction is an important energy intensive unit operation essential for bioenergy conversion process and densification to reduce transportation costs (Bitra et al., 2009; Soucek et al., 2003). Energy consumption of grinding biomass depends on initial particle size, moisture content, material properties, feed rate of the material and machine variables (Lopo, 2002). A comprehensive summary of literature review on size reduction of lignocellulosic biomass is provided in Table 4.

\begin{tabular}{|c|c|c|c|c|}
\hline $\begin{array}{l}\text { Type of } \\
\text { Choppers/ } \\
\text { Grinders }\end{array}$ & Biomass & $\begin{array}{c}\text { Parameters Measured and } \\
\text { Correlations }\end{array}$ & Observations & Reference \\
\hline Hammer Mill & $\begin{array}{l}\text { Non-Treated and } \\
\text { Steam Exploded } \\
\text { Barley, Canola, } \\
\text { Oat and Wheat } \\
\text { Straw }\end{array}$ & $\begin{array}{l}\text { - Hammer mill screen size (from } \\
1.6 \text { to } 30.0 \mathrm{~mm} \text { ) on Specific } \\
\text { Energy } \\
\text { - Effect of geometric mean } \\
\text { particle size on bulk density } \\
\text { - Effect of geometric mean } \\
\text { particle size on particle density } \\
\text { - Analysis on ground particle } \\
\text { size distribution }\end{array}$ & $\begin{array}{l}\text { - Negative exponential and power } \\
\text { correlation between geometric mean } \\
\text { particle size with both bulk and } \\
\text { particle density } \\
\text { - Specific energy requirement is } \\
\text { material dependent } \\
\text { - Negative power correlation between } \\
\text { hammer mill screen size and specific } \\
\text { energy } \\
\text { - Shapiro-Wilk Test for normality was } \\
\text { performed }\end{array}$ & $\begin{array}{l}\text { Adapa et al., } \\
\text { 2011a }\end{array}$ \\
\hline Tub Grinder & $\begin{array}{l}\text { Rectangular } \\
\text { Wheat Straw } \\
\text { Bales, Round } \\
\text { Rice Straw and } \\
\text { Corn Stover Bales }\end{array}$ & $\begin{array}{l}\text { - Effect of screen sizes (from } 12.7 \\
\text { to } 50.8 \mathrm{~mm} \text { ) on Specific Energy } \\
\text { - Effect of screen sizes on } \\
\text { grinding rate } \\
\text { - Analysis on ground particle } \\
\text { size distribution }\end{array}$ & $\begin{array}{l}\text { - Positive correlation between screen } \\
\text { size and grinding rate } \\
\text { - Positive correlation between tub } \\
\text { rotational speed and grinding rate } \\
\text { - Specific Energy is material dependent } \\
\text { - Negative power/ exponential } \\
\text { correlation between screen size and } \\
\text { specific energy }\end{array}$ & $\begin{array}{l}\text { Arthur et al., } \\
1982\end{array}$ \\
\hline Hammer Mill & $\begin{array}{l}\text { Coastal } \\
\text { Bermudagrass }\end{array}$ & $\begin{array}{l}\text { - Effect of moisture content on } \\
\text { Specific Energy } \\
\text { - Effect of feed rate on Specific } \\
\text { Energy }\end{array}$ & $\begin{array}{l}\text { Positive correlation between moisture } \\
\text { content and specific energy } \\
\text { - Positive correlation between feed rate } \\
\text { and specific energy }\end{array}$ & Balk, 1964 \\
\hline Hammer Mill & $\begin{array}{l}\text { Wheat Straw and } \\
\text { Corn Stover }\end{array}$ & $\begin{array}{l}\text { - Effect of operating speeds } \\
\text { (from } 2000 \text { to } 3600 \mathrm{rpm} \text { ) on } \\
\text { Specific Energy } \\
\text { - Effect of hammer angles (90॰ } \\
\text { and } 30^{\circ} \text { hammers) on Specific } \\
\text { Energy } \\
\text { - Analysis on ground particle } \\
\text { size distribution }\end{array}$ & $\begin{array}{l}\text { Positive correlation between operating } \\
\text { speed and specific energy } \\
\text { - Geometric mean particle diameter } \\
\text { decreased with an increase in hammer } \\
\text { mill speed } \\
\text { - Specific energy increased with a } \\
\text { decrease in hammer angle }\end{array}$ & $\begin{array}{l}\text { Bitra et al., } \\
2009\end{array}$ \\
\hline $\begin{array}{l}\text { Knife and } \\
\text { Hammer Mills }\end{array}$ & $\begin{array}{l}\text { Hardwood } \\
\text { Chips, Wheat } \\
\text { Straw and Corn } \\
\text { Stover }\end{array}$ & $\begin{array}{l}\text { Effect of screen size (from } 1.6 \\
\text { to } 12.7 \mathrm{~mm} \text { ) on specific energy }\end{array}$ & $\begin{array}{l}\text { - Negative correlation between screen } \\
\text { size and specific energy } \\
\text { - Specific Energy is material dependent }\end{array}$ & $\begin{array}{l}\text { Cadoche and } \\
\text { López, } 1989\end{array}$ \\
\hline Hammer Mill & $\begin{array}{l}\text { Red Winter } \\
\text { Wheat Straw }\end{array}$ & $\begin{array}{l}\text { - Effect of screen size (from } 1.59 \\
\text { to } 4.76 \mathrm{~mm} \text { ) on specific energy } \\
\text { - Effect of feed rate (from } 1.5 \text { to } \\
2.5 \mathrm{~kg} / \mathrm{min} \text { ) on specific energy }\end{array}$ & $\begin{array}{l}\text { - Negative correlation was observed } \\
\text { between screen size and specific } \\
\text { energy } \\
\text { - Feed rate did not have significant } \\
\text { effect on specific energy }\end{array}$ & $\begin{array}{l}\text { Fang et al., } \\
1997\end{array}$ \\
\hline
\end{tabular}




\begin{tabular}{|c|c|c|c|c|}
\hline $\begin{array}{l}\text { Type of } \\
\text { Choppers/ } \\
\text { Grinders }\end{array}$ & Biomass & $\begin{array}{c}\text { Parameters Measured and } \\
\text { Correlations }\end{array}$ & Observations & Reference \\
\hline Hammer Mill & Wheat Straw & $\begin{array}{l}\text { - Effect of screen size ( } 3.2 \text { and } 1.6 \\
\text { mm) on Specific Energy } \\
\text { - Analysis on ground particle } \\
\text { size distribution }\end{array}$ & $\begin{array}{l}\text { Negative correlation between specific } \\
\text { energy and screen size }\end{array}$ & $\begin{array}{l}\text { Himmel et } \\
\text { al., } 1985\end{array}$ \\
\hline Tub Grinders & $\begin{array}{l}\text { Round Bales of } \\
\text { Corn Stover and } \\
\text { Perennial Grasses }\end{array}$ & $\begin{array}{l}\text { - Effect of screen size (from } 19.1 \\
\text { to } 127.0 \mathrm{~mm} \text { ) on Specific } \\
\text { Energy } \\
\text { - Effect of screen size on } \\
\text { throughput } \\
\text { - Effect of screen size on bulk } \\
\text { and particle densities }\end{array}$ & $\begin{array}{l}\text { - Negative correlation between screen } \\
\text { size and bulk density } \\
\text { - Positive correlation between screen } \\
\text { size and particle density } \\
\text { - Negative correlation between screen } \\
\text { size and specific energy } \\
\text { - Positive correlation between screen } \\
\text { size and throughput }\end{array}$ & $\begin{array}{l}\text { Kaliyan et al., } \\
2010\end{array}$ \\
\hline Hammer Mill & $\begin{array}{l}\text { Barley Straw, } \\
\text { Corn Stover and } \\
\text { Switchgrass }\end{array}$ & $\begin{array}{l}\text { - Effect of Screen Sizes (3.2, } 1.6 \\
\text { and } 0.8 \mathrm{~mm} \text { ) on Specific Energy } \\
\text { - Effect of Moisture Content (8\% } \\
\text { and } 12 \% \mathrm{wb} \text { ) on Specific } \\
\text { Energy } \\
\text { - Correlation between bulk and } \\
\text { particle densities and } \\
\text { geometric mean diameter } \\
\text { - Analysis on ground particle } \\
\text { size distribution }\end{array}$ & $\begin{array}{l}\text { - Negative linear correlation between } \\
\text { specific energy and hammer mill } \\
\text { screen size at } 8 \% \mathrm{mc} \\
\text { - Quadratic correlation between specific } \\
\text { energy and hammer mill screen size at } \\
12 \% \mathrm{mc} \\
\text { - Polynomial relations for bulk and } \\
\text { particle densities with geometric mean } \\
\text { particle diameters }\end{array}$ & $\begin{array}{l}\text { Mani et al., } \\
2004\end{array}$ \\
\hline Hammer Mill & $\begin{array}{l}\text { Oat Straw, Rattle } \\
\text { Grass and } \\
\text { Miscanthus }\end{array}$ & $\begin{array}{l}\text { - Effect of Screen size (from } 1.0 \\
\text { to } 10.0 \mathrm{~mm} \text { ) on specific energy } \\
\text { - Effect of moisture content on } \\
\text { specific energy }\end{array}$ & $\begin{array}{l}\text { - Negative power correlation between } \\
\text { screen size and specific energy } \\
\text { - Positive correlation between moisture } \\
\text { content and specific energy; } \\
\text { significantly higher specific energy is } \\
\text { required at smaller screen sizes }\end{array}$ & $\begin{array}{l}\text { Soucek et al., } \\
2003\end{array}$ \\
\hline Hammer Mill & Corn Stover & $\begin{array}{l}\text { - Effect of hammer thickness ( } 6.4 \\
\text { and } 3.2 \mathrm{~mm} \text { ) on Specific Energy } \\
\text { - Effect of hammer thickness (6.4 } \\
\text { and } 3.2 \mathrm{~mm} \text { ) on Grinding Rate } \\
\text { - Effect of hammer tip speed ( } 54 \\
\text { to } 86 \mathrm{~m} / \mathrm{s} \text { ) on Specific Energy }\end{array}$ & $\begin{array}{l}\text { - Negative correlation between hammer } \\
\text { thickness and Specific Energy } \\
\text { - Negative correlation between hammer } \\
\text { thickness and Grinding Rate } \\
\text { - Positive correlation between hammer } \\
\text { tip speed and Specific Energy }\end{array}$ & $\begin{array}{l}\text { Vigneault et } \\
\text { al., } 1992\end{array}$ \\
\hline Knife Mill & $\begin{array}{l}\text { Switchgrass, } \\
\text { Corn Stover, and } \\
\text { Wheat Straw }\end{array}$ & $\begin{array}{l}\text { - Effect of rotational speed (from } \\
250 \text { to } 500 \mathrm{rpm} \text { ) on specific } \\
\text { energy } \\
\text { - Analysis on ground particle } \\
\text { size distribution }\end{array}$ & $\begin{array}{l}\text { - Positive correlation between rotational } \\
\text { speed and specific energy } \\
\text { - Screen size has significant effect on } \\
\text { particle size distribution }\end{array}$ & $\begin{array}{l}\text { Womac et al., } \\
2007\end{array}$ \\
\hline
\end{tabular}

Table 4. A comprehensive summary of literature review on size reduction of lignocellulosic biomass.

\subsection{Chopping}

Baled agricultural biomass from the field does not have good flowing characteristics and may not flow easily into grinders such as hammer mills and disc refiners. Therefore, biomass needs to be chopped with a chopper (rotary shear shredder)/ knife mill/ tub grinder to accommodate bulk flow and uniformity of feed rate. A chopper, knife cutter, or knife mill is often used for coarse size reduction $(>50 \mathrm{~mm})$ of stalk, straw, and grass feed stocks (Bitra et al., 2009). Knife mills reportedly worked successfully for shredding forages under various crop and machine conditions (Cadoche and López, 1989).

Bitra et al. (2009) reported that the total specific energy (including energy to operate the knife mill) for agricultural biomass chopping increases with knife mill speed. The total 
specific energy for knife mill and tub grinder has been observed to have negative correlation with screen size and mass feed rate (Arthur et al., 1982; Bitra et al., 2009; Himmel et al., 1985). However, grinding rate (throughput) increases with an increase in screen size (Arthur et al., 1982).

For tub grinders, an increase in screen size results in an increase in geometric mean length of particles and throughput, but a decrease in bulk density of the particles and specific energy consumption (Kaliyan et al., 2010).

\subsection{Hammer mill grinding}

Typically, hammer mills are used in forage processing industry as they are relatively inexpensive, easy to operate and produces wide range of particles (Lopo, 2002). Hammer mills have achieved merit because of their ability to finely grind a greater variety of materials than any other machines (Scholten et al., 1985). The performance of a hammer mill is measured in terms of energy consumption and geometric mean diameter and particle size distribution of the ground product (Adapa et al., 2011a; Mani et al., 2004).

Screen Size: Hammer mill screen opening size was the most significant factor affecting mill performance (Fang et al., 1997) and also has significant effect on mean particle size (Pfost and Headley, 1971). The specific energy required to grind agricultural biomass significantly increases with a decrease in hammer mill screen size and shows a negative power correlation (Arthur et al., 1982; Soucek et al., 2003). Similarly, Adapa et al. (2011a) reported negative correlation between specific energy and particle size of biomass as affected by hammer mill screen sizes. However, two other studies reported a second-order polynomial relationship between the specific energy requirements for grinding biomass (Mani et al. 2004; Sitkei, 1986). Usually, the mean geometric particle size for any particular biomass decreases with a decrease in hammer mill screen size (Adapa et al., 2011a). It has been reported that wider particle size distribution is suitable for compaction (pelleting/ briquetting) process (Adapa et al., 2011a; Mani et al., 2004). During compaction, smaller (fine) particles rearrange and fill in the void space of larger (coarse) particles producing denser and durable compacts (Tabil, 1996).

Operating Speed (Peripheral Velocity): The speed has a significant effect on mean particle size (Pfost and Headley, 1971). The total specific energy of hammer mill grinding has direct correlation to an increase in hammer tip speed (Bitra et al., 2009; Vigneault et al., 1992). High speed hammer mills with smaller diameter rotors are good for fine or hard-to-grind material. However, at high tip speeds, the material moves around the mill parallel to the screen surface making the openings only partially effective. At slower speeds, the material impinges on the screen at a greater angle causing greater amounts of coarser feed to pass through (Balk, 1964).

Hammer Angles and Thickness: The direct energy input for grinding also depends on hammer angles. In general, the specific energy for grinding decreases with an increase in hammer degrees (Bitra et al., 2009). In addition, the specific energy for grinding increases with an increase in hammer thickness (Vigneault et al., 1992).

Material Moisture Content and Feed Rate: A positive correlation has been reported between moisture content and specific energy consumption for grinding of agricultural biomass (Balk, 1964; Mani et al., 2004; Soucek et al., 2003). Feeding rate also has significant effect on specific energy consumption during hammer mill grinding and has positive correlation (O’Dogherty, 1982). 
Bulk and Particle Densities, and Geometric Mean Particle Size: Usually, the bulk and particle density of agricultural straw significantly increases with a decrease in hammer mill screen size (Adapa et al., 2011a). The geometric mean particle size of pre-treated straw is usually smaller than that of the non-treated straw. This could be due to the fact that application of pre-treatment disrupts/ disintegrates the lignocellulosic structure of the biomass (Sokhansanj et al., 2005) leading to lower shear strength (easier to grind the straw).

\subsection{Physical and frictional properties of biomass}

Bulk Density: The goal of densification is to increase the bulk density of agricultural straw to facilitate economic storage, transportation and handling of the material. In addition, densification results in an increase in the net calorific content per unit volume. The bulk density of agricultural biomass depends on the type of biomass, moisture content, grind size, and pre-treatment (Mani et al., 2006). Lower bulk densities, and concerns with uneven and low flowability of straw grinds are critical issues to sustainable production of pellets using pellet mills (Adapa et al., 2010c; Larsson et al., 2008).

Typically, the bulk density of ground straw increases with a decrease in hammer mill screen size. Also, pre-treatments usually results in a decrease in bulk density since the organized lignocellulosic structure of biomass is disturbed/ disintegrated. In addition, the bulk density and geometric mean particle size of material is correlated by either power or exponential relations (Adapa et al., 2010b; Mani et al., 2004). Table 5 shows a summary of average bulk density of various agricultural biomasses ground using a hammer mill.

Particle Density: Particle size of the grinds will have direct effect on the final pellet density. Theoretically, the density of pellet can be as high as the particle density of the ground biomass. Similar to bulk density, particle density also depends on the type of biomass, moisture content, grind size, and pre-treatment (Adapa et al., 2010b). The particle density is observed to have negative correlation with hammer mill screen size. Application of pretreatment increases the particle density since disturbance/ disintegration of lignocellulosic structure results in finer components (Adapa et al., 2010b). Table 5 shows a summary of average particle density of various agricultural biomasses ground using a hammer mill.

Geometric Mean Particle Size and Distribution: It has been reported that wider particle size distribution is suitable for compaction (pelleting/briquetting) process (Mani et al., 2004a). During compaction, smaller (fine) particles rearrange and fill in the void space of larger (coarse) particles producing denser and durable compacts (Tabil, 1996). Therefore, ideally the grinds should be normally distributed, should have near zero skewness and lower peak than expected for the normal and wider distribution of data (negative Kurtosis values). In addition, a decrease in the biomass grind size has been observed to have a positive effect on pellet mill throughput (Adapa et al., 2004).

Frictional Properties: Prior to densification, biomass grinds need to be efficiently stored, handled and transported. Physical and frictional properties of biomass have significant effect on design of new and modification of existing bins, hoppers and feeders (Fasina et al., 2006). The frictional behavior of biomass grinds in all engineering applications is described by two independent parameters: the coefficient of internal friction, and the coefficient of wall friction. The former determines the stress distribution within particles undergoing strain, and the latter describes the magnitude of the stresses between the particle and the walls of its container (Seville et al., 1997). The classic law of friction states that frictional force is directly proportional 
to the total force that acts normal to the shear surfaces (Chancellor, 1994; Chung and Verma, 1989; Larsson, 2010). Frictional force depends on the nature of the materials in contact but is independent of the area of contact or sliding velocity (Mohsenin, 1970). Material properties such as moisture content and particle size affect the frictional properties and densification performance of an individual feedstock (Larsson 2010; Shaw and Tabil, 2006). In addition, the determination of coefficient of friction is essential for the design of production and handling equipment and in storage structures (Adapa et al., 2010a; Puchalski and Brusewitz, 1996). A comprehensive summary of literature review on coefficient of internal friction and cohesion of agricultural biomass is provided in Table 6.

Predominantly, a linear correlation exists between normal and shear stress for agricultural straw grinds (Adapa et al., 2010a; Chevanan et al., 2008; Richter, 1954) at any specific hammer mill screen size. An increase in hammer mill screen size significantly decreases the shear stress for ground straw at any specific normal stress (Adapa et al., 2010a).

The correlation for coefficient of internal friction and cohesion with average geometric mean particle sizes for agricultural straw grinds is provided in Adapa et al. (2010a). These correlations can be used to predict the coefficient of internal friction (slope of the linear plot) and the cohesion (intercept of the linear plot) for various geometric mean particle sizes. In general, the coefficient of internal friction for ground agricultural straw decreases with an increase in average geometric mean particle diameter. The coefficient of cohesion for straw grinds increases with an increase in average geometric mean particle size (Adapa et al., 2010a).

\begin{tabular}{|c|c|c|c|c|c|c|}
\hline Biomass & $\begin{array}{l}\text { Hammer } \\
\text { Mill Screen } \\
\text { Size (mm) }\end{array}$ & $\begin{array}{c}\text { Moisture } \\
\text { Content }(\%, \\
\text { wb) }\end{array}$ & $\begin{array}{c}\text { Geometric } \\
\text { Mean Particle } \\
\text { Diameter (mm) }\end{array}$ & $\begin{array}{c}\text { Bulk } \\
\text { Density } \\
(\mathrm{kg} / \mathrm{m} 3)\end{array}$ & $\begin{array}{l}\text { Particle } \\
\text { Density } \\
(\mathrm{kg} / \mathrm{m} 3)\end{array}$ & Reference \\
\hline \multirow{3}{*}{ Barley } & 6.4 & 8.9 & 0.88 & 96 & 1046 & \multirow{3}{*}{ Adapa et al., 2011a } \\
\hline & 3.2 & 5.3 & 0.46 & 149 & 1089 & \\
\hline & 1.6 & 7.8 & 0.46 & 155 & 1149 & \\
\hline \multirow{3}{*}{ Canola } & 6.4 & 12.6 & 0.89 & 144 & 1019 & \multirow{3}{*}{ Adapa et al., 2011a } \\
\hline & 3.2 & 9.2 & 0.52 & 190 & 1192 & \\
\hline & 1.6 & 8.3 & 0.37 & 203 & 1309 & \\
\hline \multirow{3}{*}{ Corn Stover } & 3.2 & 6.22 & 0.41 & 131 & 1170 & \multirow{3}{*}{ Mani et al., 2004} \\
\hline & 1.6 & 6.22 & 0.26 & 156 & 1330 & \\
\hline & 0.8 & 6.22 & 0.19 & 158 & 1340 & \\
\hline \multirow{3}{*}{ Oat } & 6.4 & 10.9 & 0.94 & 111 & 873 & \multirow{3}{*}{ Adapa et al., 2011 } \\
\hline & 3.2 & 9.4 & 0.57 & 156 & 1093 & \\
\hline & 1.6 & 7.7 & 0.40 & 196 & 1240 & \\
\hline \multirow{3}{*}{ Wheat } & 6.4 & 9.5 & 0.99 & 107 & 1078 & \multirow{3}{*}{ Adapa et al., 2011a } \\
\hline & 3.2 & 9.5 & 0.72 & 141 & 1225 & \\
\hline & 1.6 & 8.6 & 0.45 & 154 & 1269 & \\
\hline
\end{tabular}

Table 5. Average bulk and particle densities of various agricultural biomasses ground using a hammer mill 


\begin{tabular}{|c|c|c|c|}
\hline Biomass & Experimental Conditions & Observations & Reference \\
\hline Corn Stover & $\begin{array}{l}\text { - Normal stress from } 10 \text { to } 200 \mathrm{kPa} \\
\text { - Hammer mill screen sizes of } 6.35 \text { and } 3.18 \\
\text { mm } \\
\text { - Moisture contents of } 7,11 \text { and } 15 \%(\mathrm{wb}) \\
\text { - Galvanized steel }\end{array}$ & $\begin{array}{l}\text { - Coefficient of wall friction increased } \\
\text { from } 0.18 \text { to } 0.26 \text { with an increase in } \\
\text { moisture from } 7 \text { to } 15 \% \\
\text { - No clear trend observed for the } \\
\text { adhesion coefficient }\end{array}$ & Mani et al., 2004 \\
\hline $\begin{array}{l}\text { Peat hull, } \\
\text { Switchgrass and } \\
\text { Poultry Litter }\end{array}$ & $\begin{array}{l}\text { - Consolidating stress from } 1.5 \text { to } 12.0 \mathrm{kPa} \\
\text { - Screen sizes from } 0.79 \text { to } 3.20 \mathrm{~mm} \\
\text { - Ring shear test }\end{array}$ & $\begin{array}{l}\text { No effect of screen size on internal } \\
\text { friction and cohesive properties }\end{array}$ & Fasina et al., 2006 \\
\hline $\begin{array}{l}\text { Peat Moss, Wheat } \\
\text { Straw, Oat Hulls } \\
\text { and Flax Shives }\end{array}$ & $\begin{array}{l}\text { - Normal stress from } 10 \text { to } 400 \mathrm{kPa} \\
\text { - Geometric mean particles sizes of } 0.74 \text { (peat } \\
\text { moss), } 0.65 \text { (wheat straw), } 0.47 \text { (oat hulls) } \\
\text { and } 0.64 \text { (flax shives) } \mathrm{mm} \\
\text { - Moisture content } 9-10 \% \text { (wb) } \\
\text { - Mild steel surface }\end{array}$ & $\begin{array}{l}\text { - Coefficient of wall friction were } 0.68 \\
\text { (peat moss), } 0.45 \text { (wheat straw), } 0.39 \\
\text { (oat hulls), and } 0.41 \text { (flax shives) } \\
\text { - Adhesion coefficients were } 0.2635 \mathrm{kPa} \\
\text { (peat moss), } 10.687 \mathrm{kPa} \text { (wheat straw), } \\
4.719 \mathrm{kPa} \text { (oat hulls), and } 16.203 \mathrm{kPa} \\
\text { (flax shives) }\end{array}$ & $\begin{array}{l}\text { Shaw and Tabil, } \\
2006\end{array}$ \\
\hline $\begin{array}{l}\text { Alfalfa, Barley } \\
\text { Straw, Wheat Straw } \\
\text { and Whole Green } \\
\text { Barley }\end{array}$ & $\begin{array}{l}\text { - Normal stress from } 200 \text { to } 735 \mathrm{kPa} \\
\text { - Moisture content for alfalfa, barley straw } \\
\text { from } 12.0 \text { to } 45.7 \% \text {, and for wheat straw at } \\
10.0 \% \text { and whole green barley at } 51.0 \%(\mathrm{wb}) \\
\text { - Chop size from } 10 \text { to } 90 \mathrm{~mm} \\
\text { - Polished steel surface }\end{array}$ & $\begin{array}{l}\text { Coefficient if friction on steel surface } \\
\text { for alfalfa and barley straw increased } \\
\text { with moisture content and was from } \\
0.15 \text { to } 0.26 \text {, and } 0.14 \text { and } 0.27 \text {, } \\
\text { respectively } \\
\text { - Coefficient of friction for wheat straw } \\
\text { and whole green barley were } 0.13 \text { and } \\
0.21 \text {, respectively } \\
\text { - No effect of chop size on coefficient of } \\
\text { internal friction on barley straw }\end{array}$ & $\begin{array}{l}\text { Afzalinia and } \\
\text { Roberge, } 2007\end{array}$ \\
\hline $\begin{array}{l}\text { Switchgrass, Wheat } \\
\text { straw, and Corn } \\
\text { Stover }\end{array}$ & $\begin{array}{l}\text { - Normal stresses from } 1.23 \text { to } 4.92 \mathrm{kPa} \\
\text { - Chop size of } 7.81 \text { and } 13.50 \mathrm{~mm} \text { for } \\
\text { switchgrass, } 7.09 \text { and } 10.39 \mathrm{~mm} \text { for wheat } \\
\text { straw, } 7.80 \text { and } 14.89 \mathrm{~mm} \text { for corn stover }\end{array}$ & $\begin{array}{l}\text { - No effect of chop size on friction } \\
\text { coefficients } \\
\text { - Coefficient of internal friction varied } \\
\text { from } 0.765 \text { to } 1.586\end{array}$ & $\begin{array}{l}\text { Chevanan et al., } \\
2008\end{array}$ \\
\hline Reed Canary Grass & $\begin{array}{l}\text { - Normal stresses of } 0.52-7.52 \mathrm{kPa} \text { (low) and } \\
\text { - } 23-275 \mathrm{MPa} \text { (high) } \\
\text { - } \text { Moisture contents from } 6.7 \text { to } 17.1 \% \text { (wb) for } \\
\text { normal stress, and } 8.9 \text { to } 27.2 \% \text { for high } \\
\text { - Screen sizes of } 4.0 \mathrm{~mm} \\
\text { - } \text { Ring shear test } \\
\text { - }\end{array}$ & $\begin{array}{l}\text { High friction value of } 0.6 \text { was obtained } \\
\text { at normal stress of } 50 \mathrm{MPa} \text { and lower } \\
\text { At low normal stresses, the coefficient } \\
\text { of kinematic wall friction (ratio of shear } \\
\text { stress and normal stress) was positively } \\
\text { correlated with moisture content and } \\
\text { negatively correlated to normal stress } \\
\text { - At high normal stresses, the coefficient } \\
\text { of kinematic wall friction was } \\
\text { negatively correlated to both moisture } \\
\text { content and normal stress }\end{array}$ & Larsson, 2010 \\
\hline $\begin{array}{l}\text { Non-Treated and } \\
\text { Steam Exploded } \\
\text { Barley, Canola, Oat } \\
\text { and Wheat Straw }\end{array}$ & $\begin{array}{l}\text { - Normal stress from } 9.8 \text { to } 39.2 \mathrm{kPa} \\
\text { - Moisture content of } 10 \%(\mathrm{wb}) \\
\text { - Screen size from } 1.6 \text { to } 6.4 \mathrm{~mm}\end{array}$ & $\begin{array}{l}\text { - No effect of screen size on shear stress } \\
\text { values } \\
\text { - Steam exploded straw had higher } \\
\text { coefficient of internal friction than non- } \\
\text { treated straw grinds } \\
\text { - Coefficient of friction for non-treated } \\
\text { barley, canola, oat and wheat straw } \\
\text { were in the range of } 0.505 \text { to } 0.584 \text {, } \\
0.661 \text { to } 0.665,0.498 \text { to } 0.590 \text {, and } 0.532 \\
\text { to } 0.591 \text {, respectively. } \\
\text { - Coefficient of friction for steam } \\
\text { exploded barley, canola, oat and wheat } \\
\text { straw were in the range of } 0.562 \text { to } \\
0.738,0.708 \text { to } 0.841,0.660 \text { to } 0.860 \text {, and } \\
0.616 \text { to } 1.036, \text { respectively }\end{array}$ & Adapa et al., 2010a \\
\hline
\end{tabular}

Table 6. A comprehensive summary of literature review on coefficient of internal friction and cohesion of agricultural biomass 


\section{Summary}

The current chapter has explored the effects of pre-treatment (chemical, physico-chemical, and biological) and pre-processing (size reduction) techniques on densification of agricultural straw resulting in high quality (density and durability) pellets. It has been determined that an increase in bulk density of biomass also increases the net calorific content per unit volume of pellets, and facilitates easy and economical storage, transport and handling of the biomass. Pre-treatment and pre-processing methods disintegrate the basic lignocellulosic structure of biomass, and change the relative composition of lignin, cellulose and hemicelluloses in the material. In addition, physical and frictional properties of agricultural straw are altered. The application of pre-treatments breaks the long-chain hydrogen bond in cellulose, making hemicelluloses amorphous, and loosening the lignin out of the lignocellulosic matrix, resulting in better quality (physically) pellets. During this process, the high molecular amorphous polysaccharides are reduced to low molecular components to become more cohesive in the presence of moisture during densification process. Particle size reduction increases the total surface area, pore size of the material and the number of contact points for inter-particle bonding in the compaction process.

It has been shown that the Fourier Transform Infrared Spectroscopy (FTIR) can be used to rapidly characterize and quantify cellulose-hemicellulose-lignin composition prior to and after application of various pre-processing and pre-treatment methods. Regression equations were developed to predict the lignocellulosic content of agricultural biomass using pure cellulose, hemicelluloses and lignin as reference samples.

\section{References}

Adapa, P.K., Tabil L.G. \& Schoenau, G.J. (2011a). Grinding Performance and Physical Properties of Non-Treated and Steam Exploded Barley, Canola, Oat and Wheat Straw. Journal of Biomass and Bioenergy, doi:10.1016/j.biombioe.2010.10.004, 35(2011), pp. 549-561.

Adapa, P.K., Tabil L.G., Schoenau, G.J., Canam, T., \& Dumonceaux, T. (2011b). Quantitative Analysis of Lignocellulosic Components of Non-Treated and Steam Exploded Barley, Canola, Oat and Wheat Straw using Fourier Transform Infrared Spectroscopy. The Journal of Agricultural Science and Technology, 5(7), (In-Press).

Adapa, P.K., Tabil L.G. \& Schoenau, G.J. (2010a). Physical and Frictional Properties of Ground Non-Treated and Steam Exploded Barley, Canola, Oat and Wheat Straw Grinds. Journal of Powder Technology, doi:10.1016/j.powtec.2010.03.038, 201(2010), pp. 230-241.

Adapa, P.K., Tabil L.G. \& Schoenau, G.J. (2010b). Pelleting Characteristics of Selected Biomass with and without Steam Explosion Pre-treatment. International Journal of Agricultural and Biological Engineering, 3(3), pp. 62-79.

Adapa, P.K., Karunakaran, C. Tabil, L.G., \& Schoenau, G.J. (2009). Potential Applications of Infrared and Raman Spectromicroscopy for Agricultural Biomass. Agricultural Engineering International: the CIGR Ejournal, Manuscript 1081, XI(February), pp. 125.

Adapa, P.K., Schoenau, G.J., Tabil, L.G., Arinze, E.A., Singh, A.. \& Dalai, A.K. (2007). Customized and value-added high quality alfalfa products - a new concept. 
Agricultural Engineering International: the CIGR Ejournal, Manuscript FP 07003 , IX(June), pp. 1-28.

Adapa, P.K., Tabil, L.G. Schoenau G.J., \& Sokhansanj, S. (2004). Pelleting characteristics of fractionated sun-cured and dehydrated alfalfa grinds. Applied Engineering in Agriculture, ASAE Transactions, 20(6), pp. 813-820.

Afzalinia, S., \& Roberge, M. (2007). Physical and mechanical properties of selected forage materials. Canadian Biosystems Engineering, 49, pp. 2.23-2.27.

Akin, D.E., Rigsby, L.L., Sethuraman, A., Morrison, W.H., Gamble, G.R., \& Eriksson, K.E.L. (1995). Alterations in structure, chemistry, and biodegradability of grass lignocellulose treated with the white rot fungi Ceriporiopsis subvermispora and Cyathus stercoreus. Applied Environmental Microbiology, 61, pp. 1591-1598.

Anglès, M.N., Ferrando, F., Farriol X., \& Salvadó, J. (2001). Suitability of steam exploded residual softwood for the production of binderless panels. Effect of the pretreatment severity and lignin addition. Biomass and Bioenergy, 21, pp. 211-224.

Arthur, J.F., Kepner, R.A., Dobie, J.B., Miller, G.E., \& Parsons, P.S. (1982). Tub grinder performance with crop and forest residues. Transactions of the ASAE, 25, pp. 14881494.

Azuma, J. I., Tanaka, F., \& Koshijima, T. (1984). Enhancement of enzymatic susceptibility of lignocellulosic wastes by microwave radiation. Journal of Fermentation Technology, 62(4), pp. 377-384.

Azzam, M. (1989). Pre-treatment of cane bagasse with alkaline hydrogen peroxide for enzymatic hydrolysis of cellulose and ethanol fermentation. Journal of Environmental Science and Health, B., 24 (4), pp. 421-433.

Bagby, M. O. (1982). In International Symposium on Ethanol from Biomass. H. E. Duckworth and E. A. Thompson, eds. 561 -569. Winnipeg, MB: The Royal Society of Canada.

Balatinecz, J.J. (1983). The Potential of Densification in Biomass Utilization. In: W.A. Cote. ed. Biomass utilization. London: Plenum Press: 181-189 p.

Balk, W.A. (1964). Energy requirements for dehydrating and pelleting coastal Bermuda grass. Transactions of the ASAE, 4, pp. 349-1, 355.

Ben-Ghedalia, D., \& Miron. J. (1981). The effect of combined chemical and enzyme treatment on the saccharification and in vitro digestion rate of wheat straw. Biotechnology and Bioengineering, 23, pp. 823-831.

Ben-Ghedalia, D., \& Shefet, G. (1983). Chemical treatments for increasing the digestibility of cotton straw. Journal of Agricultural Sciences, 100, pp. 393-400.

Bhattacharya S., Sett, S., \& Shrestha, R.M. (1989). State of the Art for Biomass Densification. Energy Sources, 11, pp. 161-182.

Binder, A., Pelloni, L., \& Fiechter, A. (1980). Delignification of straw with ozone to enhance biodegradability. Applied Microbiology and Biotechnology, 11, pp. 1-5.

Bitra, V.S.P., Womac, A.R., Chevanan, N., Miu, P.I., Igathinathane, C., Sokhansanj, S., \& Smith, D.R. (2009). Direct mechanical energy measured of hammer mill comminution of switchgarss, wheat straw, and corn stover and analysis of their particle size distributions. Powder Technology, 193(2009), pp. 32-45.

Budevska, B.O. 2002. Handbook of Vibrational Spectroscopy, Vol. 5, edited by J. M. Chalmers and P. R. Griffiths, New York: John Wiley and Sons: 3720-3732 p. 
Cadoche, L. \& López, G.D. (1989). Assessment of size reduction as a preliminary step in the production of ethanol for lignocellulosic wastes. Biological Wastes, 30, pp. 153-157.

Cara, C., Ruiz, E., Ballesteros, M., Manzanares, P., Jose Negro, M., \& Castro, E. (2008). Production of fuel ethanol from steam-explosion pretreated olive tree pruning. Fuel, 87(6), pp. 692-700.

Chabannes, M., Ruel, K., Yoshinaga, A,. Chabbert, B., Jauneau, A., Joseleau, J.P., \& Boudet, A.M. (2001). In situ analysis of lignins in transgenic tobacco reveals a differential impact of individual transformations on the spatial patterns of lignin deposition at the cellular and subcellular levels. Plant Journal, 28, pp. 271-282, doi:10.1046/j.1365313X.2001.01159.x

Chancellor, W.L. (1994). Friction between soil and equipment materials. ASAE Paper No. 941034. St. Joseph, MI.: American Society of Agricultural and Biological Engineers.

Chen, W., Lickfield, G.C., \& Yang, C.Q. (2004). Molecular modeling of cellulose in amorphous state. Part I: model building and plastic deformation study. Polymer, 45, pp. 1063-1071.

Chevanan, N., Womac, A.R. Bitra, V.S. \& Yoder, D.C. (2008). Flowability parameters for chopped switchgrass, wheat straw and corn stover. ASABE Annual International Meeting, Rhode Island, Paper No. 084162. St. Joseph, MI: American Society of Agricultural and Biological Engineers, June 29 - July 2, 12 pages.

Chico-Santamarta, L., Humphroes, A., White, D., Chaney, K., \& Godwin, R.J. (2009). Effect of Pre- and Post-Pelletization Storage of Canola (Oilseed Rape) Straw on the Quality and Properties of Pellets. ASABE Annaul International Meeting, Grand Sierra Resort and Casino, Reno, Nevada, Paper No. 096105, June 21 - 24, 17 pages.

Chung, J.H., \& Verma, L.R. (1989). Determination of friction coefficients of beans and peanuts. Transactions of the ASAE 32(2), pp. 745-750.

Crawford, R. L. (1981). Lignin biodegradation and transformation. New York: John Wiley and Sons. ISBN 0-471-05743-6.

de la Hoz, A., Diaz-Ortiz, A. \& Moreno, A. (2005). Microwaves in organic synthesis: Thermal and non-thermal microwave effects. Chemical Society Reviews, 34, pp. 164-178.

Deguchi, S., Tsujii, K., \& Horikoshi, K. (2006). Cooking Cellulose in Hot and Compressed Water. Chemical Communications, pp. 3293 - 3295, doi:10.1039/b605812d

Demirbaş, A. (2001). Biomass Resource Facilities and Biomass Conversion Processing for Fuels and Chemicals. Energy Conversion and Management, 41, pp. 1357-1378.

Drzymala, Z. (1993). Industrial briquetting - fundamentals and methods. Studies in mechanical engineering, Vol. 13 Warszawa: PWN-Polish Scientific Publishers.

Encyclopædia Britannica. (2008). Cellulose. Retrieved May 23, 2008, from Encyclopædia Britannica Online.

Esteghlalian, A., Hashimoto, A.G., Fenske, J.J., \& Penner, M.H. (1997). Modeling and optimization of the dilute-sulfuric-acid pre-treatment of corn stover, poplar and switchgrass. Bioresource Technology, 59, pp. 129-136.

Fan, L. T., Gharpuray, M. M., \& Lee, Y. H. (1987). In Cellulose Hydrolysis. Biotechnology Monographs, 57, pp. 149-187. New York, NY: Springer-Verlag.

Fang, Q., Bolloni, I., Haque, E., \& Spillman, C.K. (1997). Comparison of energy efficiency between a roller mill and a hammer mill. Applied Engineering in Agriculture, 13(35), pp. 631-635. 
Fasina, O.O, Bransby D., \& Wood, C.W. (2006). Flow properties of biomass feedstock. ASABE Annual International Meeting, Portland, Oregon, Paper No. 066149, July 912,12 pages.

Focher, B., Marzetti, A., Marsano, E., Conio, G., Tealdi, A., Cosani, A., \& Terbojevich, M. (1998). Regenerated and Graft Copolymer Fibres from Steam-Exploded Wheat Straw: Characterization and Properties. Journal of Applied Polymer Science, 67, pp. 961-974.

Fox, D.J., Gray, P.P., Dunn, N.W., \& Warwick, L.M. (1989). Comparison of alkali and steam (acid) pre-treatments of lignocellulosic materials to increase enzymic susceptibility: Evaluation under optimized pre-treatment conditions. Journal of Chemical Technology \& Biotechnology, 44, pp. 135-146.

Galbe, M., \& Zacchi, G. (2002). A review of the production of ethanol from softwood. Applied Microbiology and Biotechnology 59, pp. 618-628.

Garcia-Cubero, M.T., Gonzalez-Benito, G. Indacoechea, I. Coca, M. \& Bolado, S. (2009). Effect of ozonolysis pre-treatment on enzymatic digestibility of wheat and rye straw. Bioresource Technology, 100, pp. 1608-1613.

Garcia-Aparicio, M. P., Ballesteros, I., Gonzalez, A., Oliva, J.M., Ballesteros, M., \& Negro, M.J. (2006). Effect of inhibitors released during steam-explosion pre-treatment of barley straw on enzymatic hydrolysis. Applied Biochemistry and Biotechnology, 129(13), pp. 278-288.

Gelbrich, J., Mai, C. \& Militz, H. (2009). Evaluation of Bacterial Wood Degradation by Fourier-Transform-Infrared (FTIR) Measurements, The study has been done within the EU-project BACPOLES (EVK4-CT-2001-00043) at the University of Gottingen (2009), 6 pages.

Gould, J.M. (1984). Alkaline peroxide delignification of agricultural residues to enhance enzymatic saccharification. Biotechnology and Bioengineering, 26, pp. 46-52.

Granada, E., López González, L.M., Míguez J.L., \& Moran, J. (2002). Fuel lignocellulosic briquettes, die design and products study. Renewable Energy, 27, pp. 561-573.

Grous, W.R., Converse, A.O., \& Grethlein, H.E. (1985). Effect of Stem Explosion Pretreatment on Pore Size and Enzymatic Hydrolysis or Poplar. Enzyme Microbial Technology, 1986(8), pp. 274-280.

Harmsen, P.F.H., Huijgen, W.J.J., Bermudez Lopez, L.M., \& Bakker, R.R.C. (2010). Literature Review of Physical and Chemical Pre-treatment Processes for Lignocellulosic Biomass. Energy Research Centre of the Netherlands. Report accessed on January 2010. Web Address: http://www.ecn.nl/docs/library/report/2010/e10013.pdf

Hatakka, A.I. (1983). Pre-treatment of wheat straw by white-rot fungi for enzymic saccharification of cellulose. Applied Microbiology and Biotechnology, 18, pp. 350- 357.

Himmel, M., Tucker, M., Baker, J., Rivard, C., Oh, K., \& Grohmann, K. (1985). Comminution of biomass: Hammer and knife mills. Biotechnology and Bioengineering Symposium, 15, pp. 39-58.

Hon, D.N.-S. (1989). Cellulosic adhesives. In Adhesives from Renewable Resources, Eds. R.W. Hemmingway and A.H. Conner, 289-304. Washington, DC: American Chemical Society.

$\mathrm{Hu}$ Z., \& Wen, Z. (2008). Enhancing enzymatic digestibility of switchgrass by microwave assisted alkali pre-treatment. Biochemical Engineering Journal, 38, pp. 369-378 
Hu, Z., Wang, Y. \& Wen, Z. (2008). Alkali (NaOH) Pre-treatment of switchgrass by radio frequency-based dielectric heating. Applied Biochemistry and Biotechnology, 148, pp. 71-81.

Igathinathane, C., Womac, A.R., Sokhansanj, S., \& Narayan, S. (2008). Knife grid size reduction to pre-process packed beds of high- and low-moisture switchgrass. Bioresource Technology, 99, pp. 2254-2264.

Jackson, M. G. (1977). The alkali treatment of straws. Animal Feed Science and Technology, 2, pp. 105-130.

Jin, S. \& Chen, H. (2006). Superfine Grinding of Steam-Exploded Rice Straw and its Enzymatic Hydrolysis. Biochemical Engineering Journal, 30(2006), pp. 225-230.

Kaliyan, N., Schmidt, D.R., \& Morey, R.V. (2010). Commercial Scale Grinding of Corn Stover and Perennial Grasses. ASABE Annual International Meeting, David L. Lawrence Convention Centre, Pittsburgh, Pennsylvania, June 20-23, Paper No. 1009062, 2950 Niles Road, St. Joseph, MI 49085-9659 USA.

Kaliyan, N., \& Morey, R.V. (2006). Factors affecting strength and durability of densified products. ASABE Annual International Meeting, American Society of Agricultural and Biological Engineers, Portland, Oregon July 9-12, Paper Number 066077, 2950 Niles Road, St. Joseph, MI 49085-9659 USA.

Kashaninejad, M., \& Tabil. L.G. (2011). Effect of microwave-chemical pre-treatment on compression characteristics of biomass grinds. Biosystems Engineering, 108, pp. 3645.

Kelley, S.S., Rowell, R.M., Davis, M., Jurich, C.K., \& Ibach, R. (2004). Rapid Analysis of the Chemical Composition of Agricultural Fibres Using Near Infrared Spectroscopy and Pyrolysis Molecular Beam Mass Spectrometry. Biomass and Bioenergy, 27(2004), pp. 77-88.

Keshwani, D.R., Cheng, J.J., Burns, J.C., Li, L., \& Chiang, V. (2007). Microwave pre-treatment of switchgrass to enhance enzymatic hydrolysis. ASABE Annual Meeting Paper No. 077127, Minneapolis, MN, USA.

Kitchaiya, P., Intanakul, P., \& Krairiksh, M. (2003). Enhancement of enzymatic hydrolysis of lignocellulosic wastes by microwave pre-treatment under atmospheric pressure. Journal of Wood Chemistry and Technology, 23(2), pp. 217- 225.

Kokta, B.V., \& Ahmed, A. (1998). Chapter 6: Steam Explosion Pulping. Environmentally Friendly Technologies for the Pulp and Paper Industry, edited by Raymond A. Young and Masood Akhtar, ISBN 0-471-15770-8, John Wiley and Sons, Inc.

Kumar, P., Barrett, D.M., Delwiche, M.J., \& Stroeve, P. (2009). Methods for pre-treatment of lignocellulosic biomass for efficient hydrolysis and biofuel production. Industrial and Engineering Chemistry Research, 48, pp. 3713-3729.

Ladisch, M. R. (1989). Hydrolysis. In: Biomass Handbook. O. Kitani and C. W. Hall, eds. 434451. New York: Gordon and Breach.

Lam, P.S., Sokhansanj, S., Bi, X., Lim, C.J., Mani, S., \& Melin, S. (2008). Energetic feasibility of biomass densification with steam explosion pretreatment. CSBE Annual General Meeting; July 14-16, Poster Number CSBE08305, Vancouver, BC.

Larkin, S., Ramage, J., \& Scurlock, J. (2004). Bioenergy. In: G. Boyle. ed. Renewable energy. Power for a sustainable future: 106-146 p.

Larsson, S.H. (2010). Kinematic Wall Friction Properties of Reed Canary Grass Powder at High and Low Normal Stresses. Powder Technology, 198, pp. 108-113. 
Larsson, S.H., Thyrel, M., Geladi, P., \& Lestander, T.A. (2008). High Quality Biofuel Pellet Production from Pre-Compacted Low Density Raw Materials. Bioresource Technology, 99(2008), pp. 7176-7182.

Lebo, S. E. Jr., Gargulak, J.D., \& McNally, T.J. (2001). “Lignin”. Kirk-Othmer Encyclopedia of Chemical Technology. John Wiley \& Sons, Inc. DOI:10.1002/0471238961.12090714120914.a01.pub2. Retrieved on 2007-10-14.

Lehtikangas, P. (2001). Quality properties of palletized sawdust, logging residues and bark. Biomass and Bioenergy, 20, pp. 351-360.

Lesoing, G., Klopfenstein, T., Rush, I., \& Ward, J. (1980). Chemical treatment of wheat straw. Journal of Animal Science, 51, pp. 263-269.

Lin, Y., \& Tanaka, S. (2006). Ethanol fermentation from biomass resources: current state and prospects. Applied Microbiology and Biotechnology, 69.6, pp. 627-642.

Liu, R., Yu, H., and Huang, Y. (2005). Structure and Morphology of Cellulose in Wheat Straw. Cellulose, 12, pp. 25-34.

Lopo, P. (2002). The right grinding solution for you: roll, horizontal or vertical. Feed Management, 53(3), pp. 203-6.

Luypaert, J., Zhang, M.H., \& Massart, D.L. (2003). Feasibility Study for the Use of Near Infrared Spectroscopy in the Qualitative and Quantitative Analysis of Green Tea. Analytca Chimica Acta, 478(2003), pp. 303-312.

MacDonald, D.G., Bakhshi, N.N., Mathews, J.F., Roychowdhury, A., Bajpai, P., \& MooYoung, M. (1983). Alkali treatment of corn stover to improve sugar production by enzymatic hydrolysis. Biotechnology and Bioengineering, 25, pp. 2067-2076.

Magara K., \& Azuma, J. (1989). Microwave-irradiation of lignocellulosic materials X: Conversion of microwave-irradiated agricultural wastes into ethanol. Wood Research, 76, pp. 1-9

Mani, S., Tabil, L.G., \& Sokhansanj, S. (2006). Effects of Compressive Force, Particle Size, and Moisture Content on Mechanical Properties of Biomass Pellets from Grasses. Biomass and Bioenergy, 30(2006), pp. 648-654.

Mani, S., Tabil, L.G., \& Sokhansanj, S. (2004). Grinding performance and physical properties of wheat and barley straws, corn stover and switchgrass. Biomass and Bioenergy, 27(2004), pp. 339-52.

Mani, S., Tabil, L.G., \& Sokhansanj, S. (2003). An overview of compaction of biomass grinds. Powder Handling \& Process, 15(3), pp. 160-168.

Marra, F., Lyng, J., Romano, V., \& McKenna, B. (2007). Radio-frequency heating of foodstuff: Solution and validation of a mathematical model. Journal of Food Engineering, 79, pp. 998-1006.

McMullen, J., Fasina, O.O., Wood, C.W., \& Feng, Y. (2005). Storage and handling characteristics of pellets from poultry litter. Applied Engineering in Agriculture, 21(4), pp. 645-651.

Mohsenin, N.N. (1970). Physical Properties of Plant and Animal Materials. New York, N.Y.: Gordon and Breach Science Publishers.

Mosier, N., Wyman, C., Dale, B., Elander, R., Lee, Y.Y., Holtzapple, M., \& Ladisch, M. (2005). Features of promising technologies for pre-treatment of lignocellulosic biomass. Bioresource Technology, 96, pp. 673-686.

Murphy, J.D and K. McCarthy. (2005). Ethanol production from energy crops and wastes for use as a transport fuel in Ireland. Applied Energy, 82, pp. 148-166. 
Neely, W. C. (1984). Factors affecting the pre-treatment of biomass with gaseous ozone. Biotechnology and Bioengineering, 26, pp. 59-65.

Nelson, D.L., \& Cox, M.M. (2005). Lehninger Principles of Biochemistry. New York, NY: W.H. Freeman and Company.

Obernberger, I., \& Thek, G. (2004). Physical characterization and chemical composition of densified biomass fuels with regard to their combustion behavior. Biomass and Bioenergy, 27, pp. 653-669.

Oberndorfer, C., Pawelzik, E., \& Lucke, W. (2000). Prospects for the application of dielectric heating processes in the pre-treatment of oilseeds. European Journal of Lipid Science and Technology, 102, pp. 487-493.

O'Dogherty, M.J. (1982). A review of research on forage chopping. Journal of Agricultural Engineering Research, 27(4), pp. 267-289.

Okano, K., Kitagawa, M., Sasaki, Y., \& Watanabe, T. (2005). Conversion of Japanese red cedar (Cryptomeria japonica) into a feed for ruminants by white-rot basidiomycetes. Animal Feed Science and Technology, 120, pp. 235-243

Ooshima, H., Aso, K. Harano, Y., \& Yamamoto, T. (1984). Microwave treatment of cellulosic materials for their enzymatic hydrolysis. Biotechnology Letters, 6(5), pp. 289-294.

Overend, R.P., \& Chornet, E. (1987). Fractionation of lignocellulosics by steam-aqueous pretreatment. Philosophical Transactions of the Royal Society, London A 321, pp. 523-536.

Pfost, H.B., \& Headley, V.E. (1971). Use of logarithmic normal distribution to describe hammer mill performance. Transactions of the ASABE, 14(3), pp. 531-5.

Puchalski, C., \& Brusewitz, G.H. (1996). Coefficient of friction of watermelon. Transactions of the ASABE, 39(2), pp. 589-594.

Sánchez, Ó.J., \& Cardona, C.A. (2008). Trends in biotechnological production of fuel ethanol from different feedstocks. Bioresource Technology, 99, pp. 5270-5295.

Schell, D.J., \& Harwood, C. (1994). Milling of Lignocellulosic Biomass: Results of Pilot-Scale Testing. Applied Biochemistry and Biotechnology, 45(46), pp. 159-168.

Scholten, R.L., \& McEllhiney, R.R. (1985). The effects of prebreaking in hammer mill particle size reduction. American Society of Agricultural Engineers; Paper no. 85-3542, St. Joseph MI.

Seville, J.P.K., Tuzun, U., \& Clift, R. (1997). Processing of Particulate Solids. London, U.K.: Chapman and Hall.

Shambe, T., \& Kennedy, J.F. (1985). Acid and enzymatic hydrolysis of chaotropically pretreated millet stalk, acha and rice straws and conversion of the products to ethanol. Enzyme and Microbial Technology, 7, pp. 115-120.

Shaw, M. (2008). Feedstock and Process Variables Influencing Biomass Densification. M.Sc. Thesis, Department of Agricultural and Bioresource Engineering, University of Saskatchewan. Website: http://library2.usask.ca/theses/available/etd-03092008115636/unrestricted/Thesis.MarkShaw.FinalR3.pdf

Shaw, M.D., \& Tabil, L.G. (2006). Mechanical properties of selected biomass grinds. ASABE Annual International Meeting, Oregon Convention Center, Portland, Oregon, Paper Number 066175, July 9-12: 12 pages.

Sherman Hsu, C.P. (1997). Chapter 15: Infrared Spectroscopy, in: F. Settle, Editor, Handbook of Instrumental Techniques for Analytical Chemistry, Prentice-Hall, NJ 270.

Sitkei, G. (1986). Mechanics of agricultural materials. Amsterdam: Elsevier. 
Smola, N., \& Urleb, U. (2000). Qualitative and Quantitative Analysis of Oxytetracycline by Near-Infrared Spectroscopy. Analytica Chimica Acta, 410(2000), pp. 203-210.

Sokhansanj, S., Mani, S., Bi, X., Zaini, P., \& Tabil, L.G. (2005). Binderless pelletization of biomass. ASAE Annual International Meeting, Tampa Convention Centre, Tampa, Florida; July 17-20, Paper Number 056061, 2950 Niles Road, St. Joseph, MI 490859659 USA.

Soto, M.L., Dominguez, H., Nunez, M.J., \& Lema, J.M. (1994). Enzymatic saccharification of alkali-treated sunflower hulls. Bioresource Technology, 49, pp. 53-59.

Soucek, J., Hanzlikova, I., \& Hulta, P. (2003). A fine disintegration of plants suitable for composite biofuels production. Research in Agricultural Engineering, 49(1), pp. 7-11.

Stenberg, K., Tengborg, C., Galbe, M., \& Zacchi, G. (1998). Optimisation of steam pretreatment of SO2-impregnated mixed softwoods for ethanol production. Journal of Chemical Technology and Biotechnology, 71(4), pp. 299-308.

Sun, F., \& Chen, H. (2007). Evaluation of enzymatic hydrolysis of wheat straw pretreated by atmos-pheric glycerol autocatalysis. Journal of chemical technology and biotechnology, 82, pp. 1039-1044.

Sun, Y., \& Cheng, J. (2002). Hydrolysis of lignocellulosic materials for ethanol production: a review. Bioresource Technology 83, pp. 1-11.

Tabil, L.G. (1996). Pelleting and binding characteristics of alfalfa. Unpublished Ph.D. thesis, Department of Agricultural and Bioresource Engineering, Saskatoon, SK Canada: University of Saskatchewan.

Taherzadeh, M.J., \& Karimi, K. (2007). Acid-based hydrolysis processes for ethanol from lignocellulosic materials: a review. Bioresources, 2, pp. 472-499.

Temmerman, M., Rabier, F., Jensen, P.D., Hartmann, H., \& Bohm, T. (2006). Comparative Study of Durability Test Methods for Pellets and Briquettes. Biomass and Bioenergy, 30(11), pp. 964.

Tomas-Pejo, E., Oliva, J.M., \& Ballesteros, M. (2008). Realistic approach for full-scale bioethanol production from lignocellulose: a review. Journal of Scientific $\mathcal{E}$ Industrial Research, 67, pp. 874-884.

Tripathi, K., Iyer, P.V.R., and Kandpal, T.C. (1988). A Techno-Economic Evaluation of Biomass Briquetting in India. Biomass and Bioenergy, 14, pp. 479-488.

Tucker, M.P., Mitri, R.K., Eddy, F.P., Nguyen, Q.A., Gedvilas, L.M., \& Webb, J.D. (2000). Fourier Transform Infrared Quantification of Sugars in Pretreated Biomass Liquors. Applied Biochemistry and Biotechnology, 84-86(2000), pp. 39-50.

United States Department of Energy (USDE). (2006). Energy Efficiency and Renewable Energy - Biomass Program. Website Accessed on January 21, 2011. Web Address: http://www1.eere.energy.gov/biomass

Updegraff, D.M. (1969). Semimicro Determination of Cellulose in Biological Materials. Analytical Biochemistry, 32, pp. $420-424$.

van Dam, J.E.G., van den Oever, M.J.A., Teunissen, W., Keijsers, E.R.P., \& Peralta, A.G. (2004). Process for production of high density/high performance binderless boards from whole coconut husk. Part 1: lignin as intrinsic thermosetting binder resin. Industrial Crops and Products, 19, pp. 207-216.

Vazquez, G., Gonzalez, J., Freire, S., \& Antorrena, G. (2002). Characterization of Eucalyptus Globules and Pinus Pinaster Acetosolv Pulps Prebleached with O2 by FTIR and DRIFT Spectroscopy. Holz als Roh- und Werkstoff, 60(2002), pp. 25-30. 
Vlasenko, E.Y., Ding, H., Labavitch J.M., \& Shoemaker, S.P. (1997). Enzymatic Hydrolysis of Pretreated Rice Straw. Bioresource Technology, 59, pp. 109-119.

Vidal, P.F., \& Molinier, J. (1988). Ozonolysis of lignin-improvement of in vitro digestibility of poplar sawdust. Biomass, 16, pp. 1-17.

Vigneault, C., Rothwell, T.M., \& Bourgeois, G. (1992). Hammer mill grinding rate and energy requirements for thin and conventional hammers. Canadian Biosystems Engineering, 34, pp. 203-6.

Viola, E., Zimbardi, F., Cardinale, M., Cardinale, G., Braccio, G., \& Gambacorta, E. (2008). Processing Cereal Straws by Steam Explosion in a Pilot Plant to Enhance Digestibility in Ruminants. Bioresource Technology, 99(2008), pp. 681-689.

Womac, A.R., Igathinathane, C., Bitra, P., Miu, P., Yang, T., Sokhansanj, S., \& Narayan, S. (2007). Biomass Pre-Processing Size Reduction with Instrumented Mills. ASABE Annual International Meeting, Minneapolis Convention Centre, Minneapolis, June 17-20, Paper No. 076046, 2950 Niles Road, St. Joseph, MI 49085-9659 USA.

Zandersons, J., Gravitis, J., Zhurinsh, A., Kokorevics, A., Kallavus, U., \& Suzuki, C.K. (2004). Carbon materials obtained from self-binding sugar cane bagasse and deciduous wood residues plastics. Biomass and Bioenergy, 26, pp. 345-360.

Zimbardi, F., Viola, E., Nanna, F., Larocca, E., Cardinale, M., \& Barisano, D. (2007). Acid impregnation and steam explosion of corn stover in batch processes. Industrial Crops and Products, 26(2), pp. 195-206.

Zimbardi, F., Viggiano, D., Nanna, F., Demichele, M., Cuna, D., \& Cardinale, G. (1999). Steam Explosion of Straw in Batch and Continuous Systems. Applied Biochemistry and Biotechnology, 77-79, pp. 117-125.

Zhu, S., Wu, Y., Yu, Z., Zhang, X., Li, H., \& Gao, M. (2006a). The effect of microwave irradiation on enzymatic hydrolysis of rice straw. Bioresource Technology, 97, pp. 1964-1968.

Zhu, S., Wu, Y., Yu, Z., Chen, Q., Wu, G., Yu, F., Wang, C., \& Jin, S. (2006b). Microwaveassisted alkali pre-treatment of wheat straw and its enzymatic hydrolysis. Biosystems Engineering, 94, pp. 437-442.

Zhu, S., Wu, Y., Yu, Z., Zhang, X., Wang, C., Yu, F., \& Jin, S. (2006c). Production of ethanol from microwave-assisted alkali pretreated wheat straw. Process Biochemistry, 41, pp. $869-873$.

Zhu, S., Wu, Y., Yu, Z., Liao, J., \& Zhang, Y. (2005). Pre-treatment by microwave/alkali of rice straw and its enzymic hydrolysis. Process Biochemistry, 40, pp. 3082-3086. 


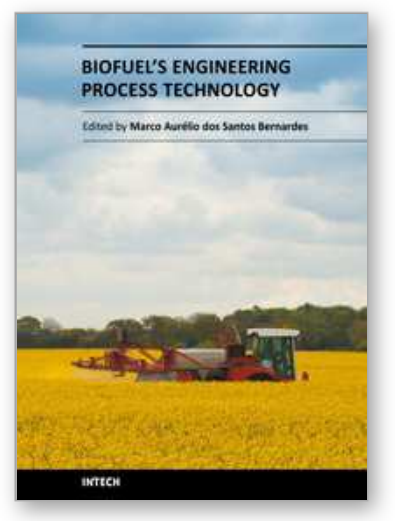

\author{
Biofuel's Engineering Process Technology \\ Edited by Dr. Marco Aurelio Dos Santos Bernardes
}

ISBN 978-953-307-480-1

Hard cover, 742 pages

Publisher InTech

Published online 01, August, 2011

Published in print edition August, 2011

This book aspires to be a comprehensive summary of current biofuels issues and thereby contribute to the understanding of this important topic. Readers will find themes including biofuels development efforts, their implications for the food industry, current and future biofuels crops, the successful Brazilian ethanol program, insights of the first, second, third and fourth biofuel generations, advanced biofuel production techniques, related waste treatment, emissions and environmental impacts, water consumption, produced allergens and toxins. Additionally, the biofuel policy discussion is expected to be continuing in the foreseeable future and the reading of the biofuels features dealt with in this book, are recommended for anyone interested in understanding this diverse and developing theme.

\title{
How to reference
}

In order to correctly reference this scholarly work, feel free to copy and paste the following:

Lope Tabil, Phani Adapa and Mahdi Kashaninejad (2011). Biomass Feedstock Pre-Processing - Part 1: PreTreatment, Biofuel's Engineering Process Technology, Dr. Marco Aurelio Dos Santos Bernardes (Ed.), ISBN: 978-953-307-480-1, InTech, Available from: http://www.intechopen.com/books/biofuel-s-engineering-processtechnology/biomass-feedstock-pre-processing-part-1-pre-treatment

\section{INTECH}

open science | open minds

\section{InTech Europe}

University Campus STeP Ri

Slavka Krautzeka 83/A

51000 Rijeka, Croatia

Phone: +385 (51) 770447

Fax: +385 (51) 686166

www.intechopen.com

\section{InTech China}

Unit 405, Office Block, Hotel Equatorial Shanghai

No.65, Yan An Road (West), Shanghai, 200040, China 中国上海市延安西路65号上海国际贵都大饭店办公楼 405 单元

Phone: +86-21-62489820

Fax: +86-21-62489821 
(C) 2011 The Author(s). Licensee IntechOpen. This chapter is distributed under the terms of the Creative Commons Attribution-NonCommercialShareAlike-3.0 License, which permits use, distribution and reproduction for non-commercial purposes, provided the original is properly cited and derivative works building on this content are distributed under the same license. 